\title{
Immunotoxicological Effects of Environmental Contaminants in Teleost Fish Reared for Aquaculture
}

\author{
Alberto Cuesta, José Meseguer and M. Ángeles Esteban \\ Fish Innate Immune System Group, Department of Cell Biology and Histology, \\ Faculty of Biology, University of Murcia, \\ Spain
}

\section{Introduction}

Contamination is one of the major problems associated with the environmental sciences. Many of the environmental pollutants affect to the different aquatic animals to certain degree depending on the toxic substance, concentration, self-life and animal behaviour and biology. Direct ingestion of environmental contaminants and bioaccumulation of toxic substances in bivalves, crustaceans, molluscs or fish for human supply is a serious task to consider in human nutrition. Furthermore, it is known that to provide the necessary proteins that need and will need the world's population must intensify efforts in production of both proteins of plant origin and animal origin. Among the latter is predicted that aquaculture will be one of the fields over the coming years will increase. In this regard, aquaculture is trying for some decades to compensate this negative balance for human consumption. Among the important issues to consider in the aquaculture business the impact of the environmental contaminants in the species produced for humans need to be controlled by the farmer. In this specific field, most of studies have evaluated the toxic effects in terms of fish viability or induction of tumors using different fish models. However, relevant fish species for aquaculture are less used in these experiments. Moreover, the impact of the environmental contaminants in the immune response of these fish, and consequently in the disease resistance, have received much less attention.

\section{Overview of the teleost fish immune response}

Fish are the first group of vertebrate animals with both innate and adaptive immune responses and are essential for proper understanding of the immune system and its evolution. The fish adaptive immune responses are less effective than in mammals because they are poikilotherms and completely dependent on the environmental temperature. Therefore, the importance of the innate immune response is more relevant, but not exclusive, in the fish disease resistance to pathogens. Overall, the mechanisms and molecules involved in the immune response are quite well conserved during the immune system evolution. However, there are major differences in terms of haematopoietic organs structure and function as well as in leucocyte distribution and function (Figure 1). 


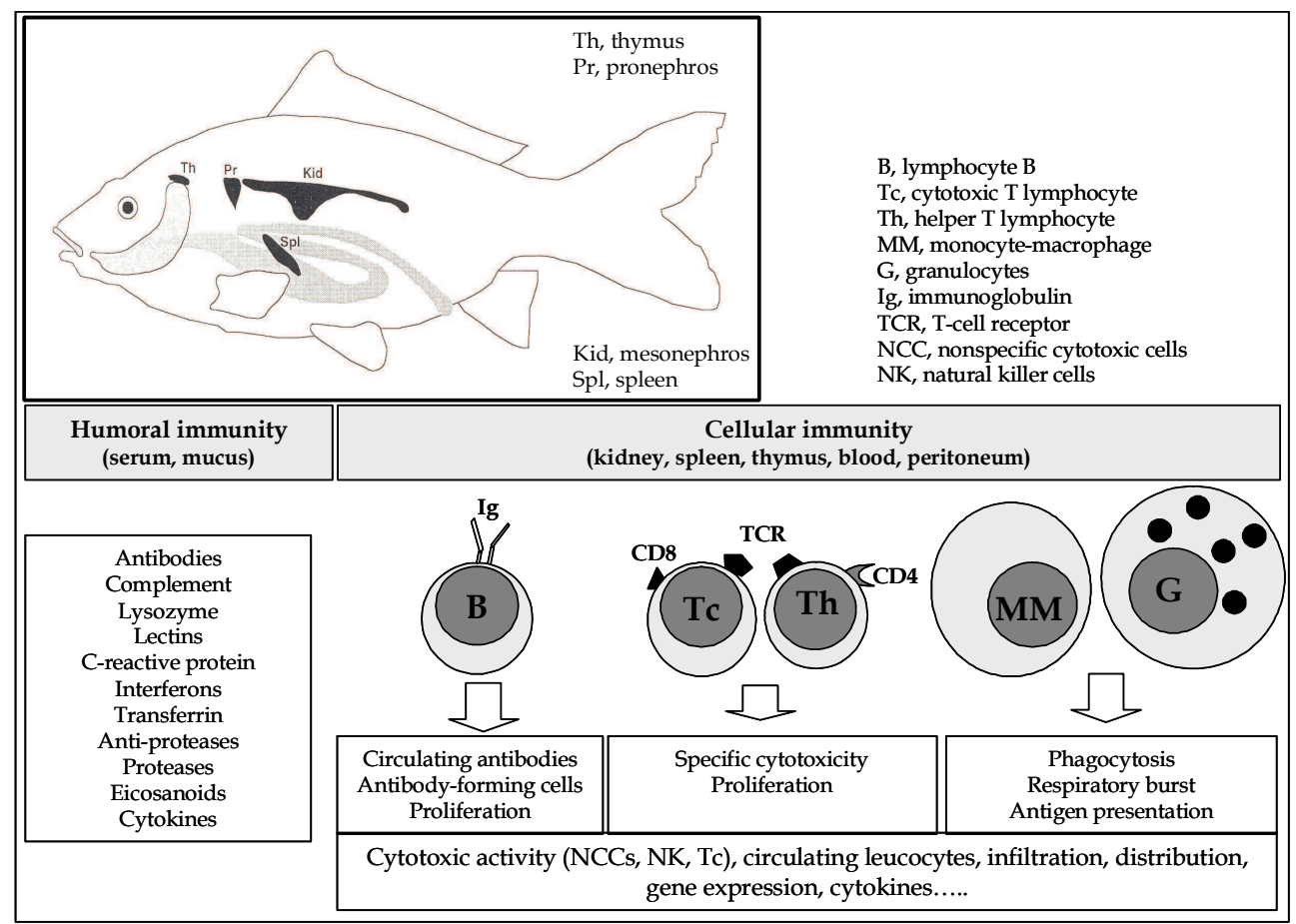

Fig. 1. Fish immune system organization (from Manning, 1998) and representative humoral and cellular immune responses used in immunotoxicological studies.

Firstly, the immune tissues are quite different since fish lack the bone marrow and lymphatic nodules (Manning, 1998). Thus, pronephros (anterior/head-kidney) is the main lympho-haematopoietic tissue in fish, whilst the posterior part or mesonephros is mainly excretory and the first site for development and B cells production. Thymus is the main tissue for $\mathrm{T}$ cells development and maturation whilst spleen is the main secondary lymphoid tissue in fish. Other important site for the immune response is the mucosal associated-lymphoid tissue (MALT), disperse in the skin, gill and gut. The leucocyte-types present in fish are quite similar between vertebrates but with some specific differences (Meseguer et al., 1994; Secombes et al., 2005; Miller et al., 1998; Rombout et al., 2005). Thus, fish lymphocytes are responsible for the production of antibodies (B cells) and the specific cellular immune response ( $\mathrm{T}$ cells). B lymphocytes express and secrete immunoglobulin $\mathrm{M}$ (IgM), respond to the mitogen lipopolysaccharide (LPS) and constitute about $30 \%$ of the circulating lymphocytes. T lymphocytes are mainly detected in the thymus, express the Tcell receptor (TCR) and proliferate with the mitogens concanavalin $A$ and phytohemagglutinin (PHA). They are responsible for the humoral and cellular immune response against T-dependent antigens by the different populations of CD4+ (Th or helper) and CD8+ (Tc or cytotoxic). Moreover, there are also subpopulations of fish lymphocytes lacking proper cell markers, Ig or TCR, and constitute the natural killer (NK) cells (Shen et al., 2002). By other side, monocyte-macrophages are the leucocytes displaying similar characteristics to both mammalian circulating monocytes and tissular macrophages. 
Moreover, they are mainly localized in kidney and spleen where they concentrate the ingested particles and aggregate in melano-macrophage (MM) centres. Granulocytes can be divided in neutrophils, eosinophils and basophils according to their staining properties but in the case of fish the distribution and functions do not fit well with their mammalian counterparts. Monocyte-macrophages and some granulocytes form the phagocytic cells involved in phagocytosis of particulated antigens and in production of a machinery of lytic enzymes and the respiratory burst reaction, in which very toxic reactive oxygen species (ROS) and nitrogen intermediates (RNI) are produced. Finally, nonspecific cytotoxic cells (NCCs) are involved in the lysis of tumor cells, virus-infected cells and parasites in a similar fashion than the mammalian NK cells (Evans et al., 1984). However, they are a heterogeneous population (lymphocytes, granulocytes and/or monocyte-macrophages) and therefore some authors talk of nonspecific cytotoxic activity more than a cellular type or population (Cuesta et al., 1999).

The humoral immune response is a compilation of proteins and glycoproteins with defense functions found in the fish plasma and other body fluids such as mucus or sexual products (Kaattari \& Piganelli, 1997). The complement system, in plasma and mucus, shows classical, alternative and lectin activation pathways with levels 5-10 times higher than in mammalian species with most of its components detected and characterized (Holland \& Lambris, 2002). Direct lytic activity against bacteria, virus and parasites is the most relevant and studied function but it also acts as opsonin, chemotactic and neutralize endotoxins (Boshra \& Sunyer, 2006). An important bacteriolytic enzyme is the lysozyme, mainly found in eggs, mucus, plasma and leucocytes (Magnadottir, 2006). There are also other innate immune factors such as acute phase proteins (C-reactive protein CRP), antimicrobial peptides, interferon (IFN), lectins, proteases, protease inhibitors or eicosanoids (Secombes, 1996; Aranishi, 1999; Bayne \& Gerwick, 2001; Robertsen, 2006; Cammarata et al., 2007; Cuesta et al., 2008a). Finally, and the most interesting in fish, Ig are the major component of the adaptive humoral immune response. Fish were thought to have only one immunoglobulin isoform, the IgM. The fish IgM is tetrameric instead of pentameric as it occurs in mammals. Both membrane and soluble forms are observed by alternative processing of the mRNA (Wilson et al., 1990). Igs are found in the membrane of the B lymphocytes and this can be used to separate Ig+ and Ig- cells. The Ig functions are antigen neutralization, precipitation, opsonization and activation of the classical pathway of the complement system. In the last years, the presence of other $\operatorname{Ig}$ isoforms (IgD, $\operatorname{IgZ}$ or $\operatorname{IgT})$ is throwing some light into the repertoire of fish immunoglobulins and their evolution in vertebrates (Hsu et al., 2006; Hikima et al., 2011).

\section{Immunotoxicological effects of environmental contaminants}

Environmental contaminants are widely distributed in aquatic environments. Although many of them are prohibited or restricted most of them are very persistent in the nature. Field and semi-field experiments are good to have suspicions about the contaminant presence but the setup of laboratory experiments with controlled parameters and precise and pure compounds are strictly necessary to understand the impact on fish immune response and their potential mechanisms. In line with the immunotoxicological studies in mammals, most of fish studies have evaluated the immune response (Figure 1) by measuring the macrophage functions (i.e. phagocytosis and ROS production), lymphoproliferative responses, host disease resistance, antibodies (circulating antibody 
levels or antibody-forming cell numbers), number of circulating leucocytes, lymphoid organ cellularity and weights (Luebke et al., 1997; Bols et al., 2001).

\subsection{Heavy metals}

Heavy metals in aquatic environments are receiving more and more attention. Among the adverse effects, they can produce mortality, alteration of sexual maturation or immunodeficiency. Some heavy metals may transform into the persistent metallic compounds with higher toxicity, which can be bioaccumulated in the organisms and magnified in the food chain, thus threatening human health (Zhou et al., 2008).

Chromium ( $\mathrm{Cr}$ ) is a naturally occurring element found in rocks, animals, plants, and soil, predominantly in its insoluble trivalent form [Cr(III)]. Unfortunately, excessive industrialization and other anthropogenic activities have led to the global occurrence of soluble Cr (VI) in concentrations above permissible levels (Velma et al., 2009). The very scarce data in vitro have demonstrated that incubation of common carp (Cyprinus carpio) leucocytes with 2-200 $\mu \mathrm{M}$ hexavalent chromium showed depressed lymphocyte proliferation upon mitogen induction, as well as phagocytic functions, at much lower concentrations that produced cytotoxicity or cell death (Steinhagen et al., 2004). Moreover, neutrophils changed their morphology and reduced the amount of ROS and RNI. In vivo studies are more abundant and diverse and have also demonstrated the direct negative effects on fish leucocyte function and viability. Thus, tilapia (Oreochromis mossambicus) specimens exposed to sublethal doses of Cr-containing tannery effluents suffered a decreased antibody production, serum lysozyme activity and production of ROS and RNI by peripheral blood leucocytes (Sudhan \& Michael, 1995; Prabakaran et al., 2007). Tilapia specimens exposed for 28 days with 0.5 and $5 \mathrm{mg} \mathrm{Cr}(\mathrm{VI}) / \mathrm{L}$ also decreased the disease resistance to bacterial infection and non-specific and specific immune response whilst the exposure with $0.05 \mathrm{mg} \mathrm{Cr}(\mathrm{VI}) / \mathrm{L}$ produced the opposite effects (Prabakaran et al., 2006). In another study, the spleen weight and the lymphocyte and leucocyte counts were significantly reduced by chronic exposure to $\mathrm{Cr}$ (III) and $\mathrm{Cr}$ (VI), producing the hexavalent form the greatest inhibitions (Arunkumar et al., 2000). In Tilapia sparrmanii, acute or chronic water exposures to potassium dichromate $(0.098 \mathrm{mg} / \mathrm{L})$ produced general haematological disorders including thrombocytopenia (Gey van Pittius et al., 1992). Moreover, and depending on the $\mathrm{pH}$, fish showed leucocytosis and leucopenia at acidic and basic $\mathrm{pH}$ values, respectively (Wepener et al., 1992). In another more extensive study, the freshwater fish Saccobranchus fossilis were exposed for 28 days to $0.1-3.2 \mathrm{mg} \mathrm{Cr}$ (IV)/L and showed important changes in humoral and cellular immune responses and disease resistance (Khangarot et al., 1999). Concretely, they found a significant increase in the spleen size accompanied by an increment of spleenic lymphocytes. However, the number of plaqueforming cells and the phagocytic activity was reduced in spleen and head-kidney leucocytes. On the other hand, at blood level, the number of lymphocytes was decreased, but neutrophils and thrombocytes were increased, as well as the level of circulating antibodies and resistance to Aeromonas hydrophila infections. Otherwise, in plaice (Pleuronectes platessa), Cr-treatment increased the number of melano-macrophage centres but reduced their size (Kranz \& Gercken, 1987). In the case of common carp and brown trout (Salmo trutta L.), 38 weeks of exposure with potassium dichromate diminished the primary and secondary humoral responses being the carp more susceptible to the heavy metal (O'Neill, 1981). In other kind of studies, the chromium exposure was carried out by dietary 
intake and resembling the food chain bioaccumulation. In this case, rainbow trout (Oncorhynchus mykiss) fed diets containing 1540 to $4110 \mathrm{ppb} \mathrm{Cr}$ showed increased serum lysozyme activity as well as respiratory burst and phagocytic activity of macrophages in a dose- and time-dependent manner (Gatta et al., 2001).

Mercury $(\mathrm{Hg})$, and derivatives such as methylmercury, are also important contaminants in aquatic environments inducing organ lesions, neurological, haematological and immunological disorders (Sweet \& Zelikoff, 2001). First evidences, in rainbow trout, described a decrease in the number of mucous-producing cells and mucus production after exposure to mercury and methylmercury, which can be associated to impaired immunity (Lock \& Overbeek, 1981). Afterwards, serum C-reactive protein was increased in freshwater murrel (Chana punctatus) (Ghosh \& Bhaattacharya, 1992) and major carp (Catla catla) (Paul et al., 1998) by exposure to mercury. However, plasmatic lysozyme of plaice was decreased after exposure to sublethal doses of mercury (Fletcher, 1986). In sharp contrast, blue gourami (Trichogaster trichopterus) showed increased kidney and plasma lysozyme activity, but at the same time reduced the production of agglutinating specific antibodies after chronic exposure to 0.045 or $0.09 \mathrm{mg} \mathrm{Hg}^{+} / \mathrm{L}$ (Low \& Sin, 1998). Further evidences have been obtained in vitro. Blue gourami lymphocytes incubated with mercury showed increased proliferation at low dosages, which was reversed by higher levels $(>0.045 \mathrm{mg} / \mathrm{L})$ (Low \& Sin, 1998). In the marine fish Sciaenops ocellatus, mercury treatment $(\leq 10 \mu \mathrm{M})$ produced a high-dose inhibition and a low-dose activation of leukocytes as determined by Ca-mobilization and tyrosyne phosphorilation of proteins (MacDougal et al., 1996). More recently, in the European sea bass (Dicentracrchus labrax), in vitro treatment with $\mathrm{HgCl}_{2}$ induced apoptosis in head-kidney macrophages as well as reduced the ROS production and the benefits of macrophage-activating factors (MAF) (Sarmento et al., 2004).

Cadmium $(\mathrm{Cd})$ is a nonessential heavy metal causing great toxicity. Among the first observations, Robohm (1986) found that Cd treatment inhibited the antibody levels in cunners (Tautogolabrus adspersus) and enhanced the antibody levels and chemotactic activity of peritoneal exudate cells in striped bass (Morone saxatilis). In rainbow trout exposed to 2 $\mathrm{ppb}$ of $\mathrm{Cd}$, the same level found in some contaminated waters, the lysozyme activity was unaffected while the macrophage functions, phagocytosis and production of ROS, were significantly impaired (Zelikoff et al., 1995). These authors also demonstrated that Japanese medaka (Oryzias latipes) leucocytes increased their production of ROS and phagocytic functions without any change in many haematological parameters or antibody levels (Zelikoff et al., 1996). In the European sea bass, while in vivo exposure had a similar inhibitory effect on phagocytic functions the in vitro treatment produced an increment (Bennani et al., 1996). In the case of juvenile common carp experimentally infected with the blood parasite, Sanguinicola inermis (Trematoda: Sanguinicolidae) there were tissue changes and while the counts of neutrophils, eosinophils and thrombocytes increased in the thymus the number of neutrophils in the pronephros was reduced due to $\mathrm{Cd} 2^{+}$treatment $(0.1 \mathrm{mg} / \mathrm{L})$ (Schuwerack et al., 2003). More recently, the Cd exposure has been related to the increase of melano-macrophage centres on several fish tissues (Suresh, 2009). In the hybrid tilapia (Oreochromis niloticus $\times$ O. aureus), the $\mathrm{Cd}$ exposure increased the lysozyme activity but greatly reduced the alternative complement activity (Wu et al., 2007).

Copper $(\mathrm{Cu})$ is an essential nutrient but intensive use against fungal infections has shown to become a contaminant in some aquatic environments with immunosuppressive effects in general. S. fossilis fish exposed to sublethal $\mathrm{Cu}$ concentrations $(0.056$ to $0.32 \mathrm{mg} / \mathrm{L})$ adversely 
affected the humoral and cell-mediated immune system parameters (Khangarot et al. 1988; Khangarot \& Tripathi, 1991) and reduced the fish resistance to A. hydrophila infections (Khangarot et al., 1999). European sea bass exposed to copper also showed an inhibited phagocytosis and ROS production both in vivo and in vitro (Bennani et al., 1996). Similar findings were also recorded in other experimental fish such as rainbow trout, goldfish (Carassius auratus), Puntius gonionotus or Colossoma macropomum (Hetrick et al. 1979; Knittel, 1981; Muhvich et al., 1995; Shariff et al., 2001; Lugo et al., 2006). Both in vitro and in vivo data have also demonstrated a decrease in the NCC activity and phagocytic responses in zebrafish (Danio rerio) (Rougier et al., 1994). Strikingly, further studies in common carp have shown increased humoral and cellular immune responses after $\mathrm{Cu}$ treatment $(0.1-2.5 \mathrm{mg} / \mathrm{L})$ (Dautremepuits et al., 2004a, 2004b). Very recently, Cu-incubation of trout macrophages upregulated the expression of immune-relevant genes (interleukin-1 $\beta$ (IL-1 $\beta$ ), IL-6, tumor necrosis factor- $\alpha(\mathrm{TNF} \alpha)$, serum amyloid A (SAA) and trout C-polysaccharide binding protein (TCPBP)) trying to understand the mechanisms and regulation of the immune response by heavy metals (Teles et al., 2011).

The immunotoxic impact of other heavy metals in fish has received less attention. Thus, zinc (Zn) was able to induce lymphoproliferation and NK-cell activity against tumor cells in common carp pronephros (Ghanmi et al., 1989, 1990). In zebrafish kidney leucocytes, Zn treatment increased the NCC activity and reduced the phagocytic responses both in vitro and in vivo (Rougier et al., 1994). $\mathrm{MnCl}_{2}$ treatment also increased lymphoproliferation and NK cell activity in carp (Ghanmi et al., 1989, 1990). By contrast, Ni exposure reduced the lymphoproliferative response in medaka and deeper analysis led to the authors to suggest that the targets were the T-cells since neither the LPS-induced B-cell proliferation and antibody-forming cells were unaffected (Luebke et al., 1997). Arsenic (As) reduced the leucocyte respiratory burst, expression of some immune-relevant genes and disease resistance in zebrafish (Hermann \& Kim, 2005; Nayak et al., 2007) in a similar fashion than in the catfish Clarias batrachus (Ghosh et al., 2007; Datta et al., 2009).

\subsection{Polycyclic aromatic hydrocarbons (PAHs)}

Aquatic environments are usually contaminated by PAHs derived form industry or petroleum, which produce external abnormalities, somatic mutations, cancer and immunodepression (Skupinska et al., 2004). The most toxic and the best studied are 7,12dimethylbenz[a]anthracene (DMBA), benzo[a]pyrene (BaP) and 3-methylcholanthrene (3MC) (Davila et al., 1995). In fish, as in mammals, the immunotoxicological effects are somehow contradictory and depend on the dose and time of exposition.

Liquid creosote $(3-10 \mu \mathrm{l} / \mathrm{L})$, containing PAHs, exposure of rainbow trout produced decreased respiratory burst of head-kidney leucocytes but increased phagocytic activity and percentage of Ig+ cells at short exposition times (Karrow et al., 2001). However, after 28 days, respiratory burst and phagocytic activity returned to control levels while the count of $B$ cells remained decreased. The use of the heavily polluted Elizabeth River (Virginia, USA) has been extensively used for immunotoxicological evaluations. In the case of mummichogs (Fundulus heteroclitus), contamination produced a decrease in the levels of circulating IgM, both total and specific, and NCC activity while the plasmatic lysozyme was increased (Faisal et al., 1991a; Frederick et al., 2007). Moreover, lymphoid cells expressed higher levels of lysozyme and COX-2 (cyclooxygenase-2), the last as indicator of macrophage activation. Native fish (Leiostomus xanthurus and Trinectes maculates) from this river also showed lower 
chemotactic and phagocytic activities that those kept in clean waters, and this suppression was reversed by maintenance in clean waters for several weeks (Weeks \& Warinner, 1984; Weeks et al., 1986). Treatment of rainbow trout with $10-70 \%$ sewage plant effluents (containing PAHs among other contaminants) also reduced the number of circulating lymphocytes but increased their in vitro proliferation capacity (Hoeger et al., 2004). Strikingly, this effluent failed to alter any other immune functions such as respiratory burst, phagocytosis, lysozyme activity, leucocyte populations other than lymphocytes and $A$. salmonicida-specific IgM production. Intraperitoneal (ip) injection of diesel oil-based drilling mud extracts produced no effect on IgM levels and complement activity, suppression of serum lysozyme and elevated head-kidney lymphocyte proliferation in response to phytohemagglutinin (Tahir \& Secombes, 1995). Petroleum-containing sediments also affected the immune response of flounder (Pseudopleuronectes americanus) since the number of melano-macrophage centres were diminished (Payne \& Fancey, 1989). Deeper studies have evaluated the effects of heavy oil contamination (3.8 g/L for 3 days) in the Japanese flounder (Paralichthys olivaceus) using cDNA microarrays (Nakayama et al., 2008). They have found an alteration of expression in immune-related genes including down-regulation of immunoglobulin light chain, CD45, major histocompatibility complex class II antigens and macrophage colony-stimulating factor precursor, and up-regulation of interleukin-8 and lysozyme. Moreover, in vitro incubation with oils, pure and single PAHs, of European sea bass plasma produced significant changes in lysozyme and alternative complement activities indicating that these contaminants caused changes in the production of them by the leucocytes but also directly affects the enzymatic activity (Bado-Nilles et al., 2009). Similarly, PAHs mixture spiked-sediments $(10 \mathrm{mg} / \mathrm{kg}$ dry $\mathrm{wt})$ failed to change the serum lysozyme but reduced the ROS activity of kidney leucocytes of dab (Limanda limanda) (Hutchinson et al., 2003) while decreased the number of circulating lymphocytes (Khan, 2003). In the marine fish spot, L. xanthurus, exposed to PAH-contaminated sediments the Tlymphocyte proliferation was suppressed but the B-cell proliferation was greatly increased (Faisal et al., 1991b). Rainbow trout fed diets containing 0.66 or $7.82 \mu \mathrm{g}$ PAH mixtures/g bw/day resulted in suppressed disease resistance against bacteria (Bravo et al., 2011).

Regarding the effects of single and pure PAHs, injections of DMBA $(0.6$ or $12.7 \mathrm{mg} / \mathrm{kg}$ body weight-bw) depressed the number of plaque-forming cells in head-kidney and spleen to Tindependent antigens in Chinook salmon (Oncorhynchus tshawytscha) (Arkoosh et al., 1994). Injection of tilapia (Oreochromis niloticus) with DMBA (25 or $75 \mathrm{mg} / \mathrm{kg}$ bw) produced hipocellularity in spleen and head-kidney whilst phagocytosis and respiratory burst activity were not altered unless mortality occurred (Hart et al., 1998) similarly to the unaffected trout phagocytosis (Spitsbergen et al., 1986). By contrast, i.p. injection of 1-100 mg DMBA/kg bw to oyster toadfish (Opsanus tau) resulted in a peritoneal macrophage activity suppression in essentially a linear fashion, whereas NCC activity was virtually obliterated at all dosages (Seeley \& Weeks-Perkins, 1997). BaP suppressed B cell immunity in tilapia at $15 \mathrm{mg} / \mathrm{kg}$ while increased at $25 \mathrm{mg} / \mathrm{kg}$ (Smith et al., 1999). Injection of $5-50 \mathrm{mg} / \mathrm{kg}$ also produced important histological changes in pronephros (reduction of lymphoid elements and augmentation of immune cells in apoptosis) and while the phagocytic activity was unaltered the respiratory burst was reduced (Holladay et al., 1998). In Japanese medaka, BaP injection (2-200 $\mathrm{mg} / \mathrm{kg} \mathrm{bw})$ greatly reduced lymphocyte proliferation and number of antibodyforming cells (Carlson et al., 2002, 2004). In European sea bass, ip injection of BaP $(20 \mathrm{mg} / \mathrm{kg}$ bw) significantly depressed the leucocyte phagocytosis and completely abrogated the ROS 
production (Lemaire-Gony et al., 1995). In rainbow trout, BaP and BaA (benzo(a)anthracene) injection failed to significantly change the phagocytic activity (Walczak et al., 1987). Finally, 3-MC injection $(40 \mathrm{mg} / \mathrm{kg} \mathrm{bw})$ into common carp increased the proliferative ability of resting circulating lymphocytes, rainbow but reduced their proliferative activity with the Band T- mitogens, as well as the macrophage respiratory burst (Reynaud et al., 2002, 2003; Reynaud \& Deschaux, 2005). Similarly, trout exposed to 3-MC increased the serum Creactive protein 10-20-fold but not affected the IFN activity of leucocytes, measured as the resistance to bluetongue virus (Winkelhake et al., 1983).

\subsection{Organochlorinated (OCs) contaminants}

This group of contaminants comprises many of the most toxic and persistent compounds for aquatic environments such as DDT and relatives, lindane, polychlorinated biphenyls (PCBs), polychlorinated dibenzo-p-dioxins (PCDDs or dioxins) or polychlorinated dibenzofurans (PCDFs or furans). These are common contaminants in water ecosystems and their residues still have toxic consequences including immunotoxicity, reproductive deficits, teratogenicity, endocrine toxicity and carcinogenicity (Ahlborg et al., 1994). Unfortunately, although OC levels detected in fish worldwide seems to be declining they still should be lowered to decrease risk for human consumers (Gómara et al., 2005).

DDT (1,1,1-trichloro-2,2-bis(p-chlorophenyl)ethane), and its metabolites DDE (p,p'-DDE and $\mathrm{o}, \mathrm{p}-\mathrm{DDE})$, are among the most important OCs in agricultural and aquatic environments. However, though no information exists regarding the direct effect of DTT on fish immunology some data are available about its derivatives. Thus, o,p-DDE treatment (10 ppm) of Chinook salmon, at fertilisation and hatch stages, failed to affect viability and growth but these fish still suffered immunosuppression one year later as consequence of the contamination (Milston et al., 2003). In vitro, p, $\mathrm{p}^{\prime}$-DDE $(0-15 \mathrm{mg} / \mathrm{L})$ produced a reduction in lymphocyte-granulocyte viability, by increasing the percentage of apoptotic cells, and in lymphocyte proliferation, in both spleen and head-kidney that was also observed in vivo (59 ppm exposure) (Misumi et al., 2005). By contrast, marine gilthead seabream leucocytes incubated with p, $\mathrm{p}^{\prime}$-DDE ( $5 \mathrm{ng}$ to $50 \mathrm{mg} / \mathrm{ml}$ ) failed to change their viability and main innate cellular immune parameters but up-regulated the expression of some immune genes (IL1beta, TNFalpha, MHCIalpha, MHCIIalpha, Mx, TLR9, IgM and TCRalpha) indicating only effects at genetic level but not in function (Cuesta et al., 2008b).

Lindane (gamma-hexachlorocyclohexane) is another OC that have focused much of the attention. Dietary intake of lindane (10-1000 ppm) failed to affect the spleen weight, serum and mucus antibody levels and phagocytosis in the common carp though most of the tissues reflected great contamination (Cossarini-Dunier, 1987; Cossarini-Dunier et al., 1987). In rainbow trout, intraperitoneal injection of lindane $(10-100 \mathrm{mg} / \mathrm{kg} \mathrm{bw})$ greatly depressed the number of antibody-secreting cells, serum lysozyme levels, respiratory burst activity and myeloperoxidase (contributes together with ROS and RNI to pathogen killing), proliferating capacity of B cells, but not of T cells, and its percentage in the head-kidney but at the same time increased the plasmatic ceruloplasmin, an acute phase protein (Dunier \& Siwicki, 1994; Dunier et al., 1994). The same group also demonstrated that oral administration of lindane (1 $\mathrm{mg} / \mathrm{kg}$ ) for 30 days significantly decreased the respiratory burst activity of head-kidney leucocytes but unaffected the lymphocyte proliferation and number of circulating $B$ lymphocytes in a similar way to the previous data in carp (Cossarini-Dunier et al., 1987; Dunier et al., 1994). Moreover, they have also demonstrated that these negative effects can be reversed by the in vitro addition of nitrogranulogen (Siwicki \& Dunier, 1994) or dietary 
intake of vitamin C (Dunier et al., 1995). Lindane bath of Nile tilapia also reduced the counts of circulating leucocytes, phagocytic activity and antibody levels (Khalaf-Allah, 1999). In vitro, lindane $(2.5-100 \mu \mathrm{M})$ treatment was able to increase ROS production in rainbow trout head-kidney phagocytes and MAF (macrophage activating factors) production by peripheral blood leucocytes, in both cases depending on the dose and with contradictory results (Betoulle et al., 2000; Duchiron et al., 2002a, 2002b). These studies also demonstrated that low lindane concentrations increase the cytoplasmatic cAMP but high doses increase the intracellular $\mathrm{Ca} 2+$, and these two factors contribute to the dual effects of induction/reduction of the leucocyte immune functions produced by lindane treatment in leucocytes (Betoulle et al., 2000; Duchiron et al., 2002a, 2002b). In gilthead seabream, headkidney leucocyte incubation ( $5 \mathrm{ng}$ to $50 \mu \mathrm{g} / \mathrm{ml}$ ) with lindane failed to significantly change the leucocyte viability (by necrosis and apoptosis) and innate cellular immune functions (phagocytosis, respiratory burst and cell-mediated cytotoxicity) but strikingly increased the expression of many immune-related genes (IL-1beta, TNFalpha, MHCIalpha, MHCIIalpha, Mx, TLR9, IgML and TCRalpha) (Cuesta et al., 2008b).

PCBs, with theoretically 209 distinct congeners, may be divided into those with coplanar geometry, the most toxic as they bind and activate AhR (hydrocarbon receptors) and CYP1A (cytochrome P4501A) expression, while noncoplanar congeners can interfere with AhR signalling but also affect cells via AhR-independent pathways (Duffy \& Zelikoff, 2006). Immunotoxicological effects of PCB mixtures, such as Arochlor, have been evaluated in fish. Thus, Aroclor 1254 depressed plaque-forming cells in head-kidney and spleen to a Tindependent antigen in Chinook salmon after ip injection (Arkoosh et al., 1994). However, it failed to modulate the innate disease resistance and antibody production by oral administration of environmental doses in the same fish (Powell et al., 2003). In Artic charr (Salvelinus alpinus), diets containing $100 \mathrm{mg}$ Aroclor 1254/ kg diet resulted in increased disease susceptibility to furunculosis (Maule et al., 2005). In Atlantic salmon (Salmo salar), by contrast, water exposure with 1-10 $\mu \mathrm{g} / \mathrm{L}$ produced increased $\mathrm{T}$ lymphocyte proliferation at short and long-term (Iwanowicz et al., 2005). In rainbow trout, while the C-reactive protein levels in serum were increased the leucocyte IFN and NCC activities were unchanged (Winkelhake et al., 1983; Cleland \& Sonstegard, 1987). Another study using Aroclor 1248, in the brown bullhead (Ameiurus nebulosus), have provoked a decrease in the bactericidal activity and antibody titers (Iwanowicz et al., 2009). PCBs mixture (Aroclor 1242, 1254 and 1260) failed to modify lysozyme and ROS activity in L. limanda (Hutchinson et al., 2003). Regarding the effects of pure PCBs, the congener 126 has been the most studied. PCB 126 injection $(0.01-1 \mu \mathrm{g} / \mathrm{g} \mathrm{bw})$ to Japanese medaka reduced the antibody forming cell numbers (Duffy et al., 2002) but either reduced or increased the phagocyte-mediated ROS production at 3 or 14 days post-treatment, respectively (Duffy et al., 2003). Dietary administration (100 ng/g bw) to European eel (Anguilla anguilla) completely abrogated the production of specific antibodies against a parasite (Sures \& Knopf, 2004). PCB 126 also produced a reduction of phagocyte respiratory burst and NCC activities in channel catfish (Ictalurus punctatus) at $(0.01-1 \mathrm{mg} / \mathrm{kg} \mathrm{bw}$ ) (Rice \& Schlenk, 1995). In the bluegill sunfish (Lepomis macrochirus), the coplanar PCB 126 (0.01 or 1.0 $\mu \mathrm{g} / \mathrm{g} \mathrm{bw}$ ) also slightly affected the B-lymphocyte proliferation while the noncoplanar PCB 153 ( 5.0 or $50.0 \mu \mathrm{g} / \mathrm{g} \mathrm{bw}$ ) significantly reduced the phagocyte-mediated respiratory burst activity and the B- and T- lymphocyte proliferation (Duffy \& Zelikoff, 2006). Strikingly, short incubation of rainbow trout head-kidney leucocytes with PCB $126(1 \mu \mathrm{M})$ increased the expression of IL-1 $\beta$ gene and failed to abrogate the LPS effects on gene regulation (Quabius et al., 2005). The PCB Clophen A50 (0.4-2 $\mu \mathrm{g} / \mathrm{egg})$ injected into the eggs of rainbow trout with 
pathogenic bacteria resulted in a higher disease resistance than those injected with the bacteria suggesting a direct effect on the immune response (Ekman et al., 2004).

Chlorinated dioxins, as typified by the most potent isomer TCDD $(2,3,7,8-$ tetrachlorodibenzo-p-dioxin), are also very toxic for fish. Injection of $0.1-10 \mu \mathrm{g}$ TCDD $/ \mathrm{kg} b w$ to rainbow trout resulted in very little changes in humoral and cellular immune responses (Spitsbergen et al., 1986). However, while the C-reactive protein levels in serum were increased the leucocyte production of IFN was unchanged (Winkelhake et al., 1983). In common carp, TCDD injection produced histological alterations including increase of melano-macrophage centres and reduction of lymphocyte numbers (van der Weiden et al., 1994). Further studies have also evaluated fish tissue alterations and CYP1A staining patterns have been described in European flounder (Platichthys flesus) and gilthead seabream (Grinwis et al., 2000; Ortiz-Delgado \& Sarasquete, 2004).

Some studies have also evaluated the immunotoxicological effect of other OCs. In the case of furans (PCDF), most authors have focused on other fish toxicity tests rather than in immunotoxicology. Endosulfan exposure produces developmental and neurological disorders and acts as endocrine disruptor. Rainbow trout leucocyte treatment with endosulfan inhibited the lymphoproliferative activity where the B-cells were more sensitive than the T lymphocytes (O'Halloran et al., 1996). In another study, crimson-spotted rainbowfish (Melanotaenia fluviatilis), golden perch (Macquaria ambigua) and Murray cod (Maccullochella peelii), but not silver perch (Bidyanus bidyanus), leucocytes showed decreased phagocytosis after endosulfan treatment $(10 \mathrm{mg} / \mathrm{L})$ (Harford et al., 2005). In vivo treatment of Nile tilapia for $96 \mathrm{~h}$ at $7 \mathrm{ppb}$ produced an increased phagocytosis and ROS production by spleen leucocytes, IgM levels and production of IL-2-like, but at the same time reduced the spleen viability and relative weight (Tellez-Bañuelos et al., 2009, 2010).

\subsection{Organophosphorous pesticides (OPs)}

OPs are insecticides used world-wide as an alternative to the persistent and more bioaccumulative OCs. They are potent neurotoxic and immunotoxic since are irreversible acetylcholinesterase inhibitors (Galloway and Handy, 2003). Malathion exposure (0.2-0.8 $\mathrm{mg} / \mathrm{L}$ ) of medaka resulted in reduced number of antibody-forming cells but unchanged circulating leucocyte numbers and T-cell proliferation (Beaman et al., 1999). Vaccinated Nile tilapia exposed to malathion or diazinon presented lower blood cell counts, phagocytosis and antibody levels than those unexposed (Khalaf-Allah, 1999). Diazinon exposure of bluegill had biphasic effects with immune response increases at low concentrations and depressions at high dosages (Dutta et al., 1997). In Nile tilapia, Girón-Pérez et al., (2007, 2008, 2009) have showed that diazinon altered the spleen counts and lymphocyte proliferation, serum IgM and lysozyme levels, phagocytic activity and respiratory burst depending on the exposure dose and time. Chlorpyrifos displayed little immunotoxicity, although there was a dose-dependent reduction in Murray cod lymphocytes (Harford et al., 2005). Nile tilapia exposed to the LC50 failed to change blood parameters but the phagocytic activity was significantly reduced (Girón-Pérez et al., 2006). Chlorpyrifos exposure produced an up-regulation of hsp60, hsp70 and hsp90 genes, related to the cellular stress response in Chinook salmon. Moreover, the cytokine (IL-1b, TGF-beta, Mx and insulin growth factor (IGF)-I) gene expression was unaltered or down-regulated but not affected the virus susceptibility of the fish (Eder et al., 2008, 2009). Dichlorvos and trichlorfon insecticides have been used in aquaculture against ectoparasites in the past. Trichlorfon exposure decreased the serum lysozyme, lymphocyte proliferation, respiratory burst and 
phagocytosis of common carp leucocytes (Siwicki et al., 1990; Dunier et al., 1991) but unchanged the production of specific antibodies (Cossarini-Dunier et al., 1990). Water exposure to dichlorvos failed to change the specific IgM production but altered other serum innate immune parameters (Dunier et al., 1991). Edifenphos and glyphosate exposure reduced the lymphocyte proliferation, antibody-producing cells and circulating IgM levels in Nile tilapia (el-Gendy et al., 1998). Glyphosate exposure of silver catfish (Rhamdia quelen) resulted in decreased phagocytosis and resistance to disease (Kreutz et al., 2010).

\subsection{Pyrethorids}

Pyrethroids are extensively used insecticides since they are very stable and produce low mammalian toxicity but this is very high for aquatic animals (Bradbury \& Coats, 1989). Among them, deltamethrin injection to Ancistrus multispinis increased peritoneal leucocyte numbers and production of RNI by macrophages (Pimpão et al., 2008). Short exposure to deltamethrin (30 min., 1-4 $\mu \mathrm{g} / \mathrm{L}$ ) of rainbow trout resulted in decreased serum lysozyme and IgM levels (Siwicki et al., 2010). Water exposure of rohu (Labeo rohita) to alphapermethrin produced a reduction in lysozyme activity and resistance to bacteria (Nayak et al., 2004). Rainbow trout exposure to cypermethrin failed to alter any of the immune parameters (Shelley et al., 2009). Esfenvalerate exposure produced an up-regulation of hsp60, hsp70 and hsp90 stress genes, down- or non-regulated cytokines and unaffected the virus susceptibility of the Chinook salmon (Eder et al., 2008, 2009). Using microarrays, delta smelt (Hypomesus transpacificus) exposure to esfenvalerate produced alterations in the expression of genes associated with immune responses, along with apoptosis, redox, osmotic stress, detoxification, growth and development (Connon et al., 2009).

\subsection{Organotins}

Organotin compounds or stannanes are chemical compounds based on tin (Sn) with hydrocarbon substituents showing different toxic effects. TBT (triorganotins) is specially important since it has been widely used as marine anti-biofouling agent. Injection of 0.01-1 mg TBT (tributyltin)/kg bw of channel catfish altered leucocyte counts, NCC, phagocytic and respiratory burst activities, production of specifc antibodies and number of antibodyproduceing cells (Rice et al., 1995). TBT treatment signinficantly reduced the lymphocyte numbers in spleen, the thymus volume and the leucocyte NCC activity in European flounder (P. flesus) (Grinwis et al., 2000). In rainbow trout, in vitro incubation with 2.5-500 ppb TBT and DBT (dibutyltin) reduced the lymphoproliferation activity in pronephros and spleen but failed to affect the NCC activity showing DBT higher toxicity than TBT (O'Halloran et al., 1998). In vitro incubation of several Australian fish head-kidney leucocytes with TBT or DBT depressed the phagocytic activity and reduced the numbers of lymphocytes and granulocytes (Harford et al., 2005).

\subsection{Other chemicals}

Herbicides are still widely used and end in aquatic environments producing many physiological alterations but little studies have focused on their immunotoxicological effects in fish. Herbicides mixture, containing atrazine, simazine, diuron and isoproturon, exposition of goldfish increased spleen and head-kidney ROS production and serum lysozyme but reduced the specific antibodies and resistance to bacterial infections (Fatima et al., 2007). Atrazine exposure of silver catfish resulted in decreased phagocytosis and 
resistance to disease (Kreutz et al., 2010) whilst failed to do so in common carp (CossariniDunier et al., 1987; Cossarini-Dunier \& Hattenberger, 1988). Phenols are another group of toxics. Phenol, pyrocatechol and hydroquinone decreased the cell-mediated cytotoxic activity of spleen lymphocytes in common carp (Taysse et al., 1995), pentachlorophenol reduced macrophage production of cytokines in goldfish (Chen et al., 2005) but activated phagocytosis and unaltered other immune functions and disease resistance in rainbow trout (Shelley et al., 2009). Endocrine disrupting chemicals produce population decline, an increasing incidence of cancer, inhibition of reproductive function, and developing disruption of the immune and nervous systems. However, there are very limited data concerning the role of endocrine disrupting chemicals on aquatic organism, including the fish immune response. Zebrafish embryos exposed for 3 days to 17a-ethynyestradiol, permethrin, atrazine and nonylphenol $(0.1-12.5 \mu \mathrm{g} / \mathrm{L})$ altered the expression of immunerelevant genes (TNFa, IFN, IL-1 $\beta$, IL-8, CXCL-Clc, CC-chemokines, iNOS, etc.) indicating their single and combined effects upon fish immune response (Jin et al., 2010).

\section{Conclusion}

As described above, most of the aquatic contaminants have shown either activations or suppressions in the immune response that greatly varied with the exposure route, time, dosage and fish specie with many similarities to immunotoxicological data in mammals. Therefore, although researchers do not have precise contamination biomarkers in aquatic animals some conclusions may rise: i) heavy metals contamination is usually followed by metallothionein overexpression (Misra et al., 1989; Hansen et al., 2007; Costa et al., 2009); ii) OCs exposure is concomitant to decreased number and size of melano-macrophage centres (Schmitt et al., 2005; Hinck et al., 2007); iii) immunotoxicological effects due to PHAs and PCBs are generally parallel to an increase in the activity of the detoxification proteins cytochrome P4501A (CYP1A), through the involvement of aryl hydrocarbon receptors (AhR), and/or EROD (ethoxyresorufin-O-deethylase) (Lee \& Anderson, 2005; Duffy \& Zelikoff, 2006; Reynaud \& Deschaux, 2006; Bravo et al., 2011); and iv) further and deeper studies are needed to understand the real effect of environmental contaminants in fish and the mechanisms for toxicity. Moreover, looking at the fish species studied and those subjected to aquaculture, most of the data come from wild fish, salmonids and cyprinids but other major species are almost ignored. Even further, most of the studies focus on freshwater fish and very little is known for marine species. These aspects should be covered by future works to progress in the understanding of the immunotoxicological effects and mechanisms and the consequences and risks they may have on human consumers as consequence of the bioaccumulation.

\section{Acknowledgments}

This work has been funded by national (IDI-20091041, AGL2008-05119-C02-01 and AGL2010-20801-C02-02) and regional projects (04538/GERM/06). A. Cuesta thanks to the Ministerio de Ciencia e Innovación for the Ramón y Cajal contract.

\section{References}

Ahlborg, U.G.; Becking, G.C.; Birnbaum, L.S.; Brouwer, A.; Derks, H.J.G.M.; Feeley, M.; Golor, G.; Hanberg, A.; Larsen, J.C.; Liem, A.K.D.; Safe, S.H.; Schlatter, C.; Waern, 
F.; Younes, M. \& Yrjäinheikki, E. (1994). Toxic equivalency factors for dioxin-like PCBs. Chemosphere, Vol.28, No.6, pp. 1049-1067, ISSN 0045-6535.

Aranishi, F. (1999). Possible role for cathepsins B and L in bacteriolysis by Japanese eel skin. Fish \& Shellfish Immunology, Vol.8, pp. 61-64, ISSN 1050-4648.

Arkoosh, M.R.; Clemons, E.; Myers, M. \& Casillas, E. (1994). Suppression of B-cell mediated immunity in juvenile Chinook salmon (Oncorhynchus tshawytscha) after exposure to either a polycyclic aromatic hydrocarbon or to polychlorinated biphenyls. Immunopharmacology and Immunotoxicology, Vol.16, No.2, pp. 293-314, ISSN 08923973.

Arunkumar, R.I.; Rajashekaran, P. \& Michael, R.D. (2000). Differential effect of chromium compounds on the immune response of the African mouth breeder Oreochromis mossambicus (Peter). Fish \& Shellfish Immunology, Vol.10, No. 8, pp. 667-676, ISSN $1050-4648$.

Bado-Nilles, A.; Quentel, C.; Thomas-Guyon, H. \& Le Floch, S. (2009). Effects of two oils and 16 pure polycyclic aromatic hydrocarbons on plasmatic immune parameters in the European sea bass, Dicentrarchus labrax (Linné). Toxicology in Vitro, Vol.23, No.2, pp. 235-241, ISSN 0887-2333.

Bayne, C.J. \& Gerwick, L. (2001). The acute phase response and innate immunity of fish. Developmental \& Comparative Immunology, Vol.25, No.8-9, pp. 725-743, ISSN 0145305X.

Beaman, J.R.; Finch, R.; Gardner, H.; Hoffmann, F.; Rosencrance, A. \& Zelikoff, J.T. (1999). Mammalian immunoassays for predicting the toxicity of malathion in a laboratory fish model. Journal of Toxicology and Environmental Health Part A: Current Issues, Vol.56, No.8, pp. 523-542, ISSN 1087-2620.

Bennani, N.; Schmid-Alliana, A. \& Lafaurie, M. (1996). Immunotoxic effects of copper and cadmium in the sea bass Dicentrarchus labrax. Immunopharmacology and Immunotoxicology, Vol.18, No.1, pp. 129-144, ISSN 0892-3973.

Betoulle, S.; Duchiron, C. \& Deschaux, P. (2000). Lindane differently modulates intracellular calcium levels in two populations of rainbow trout (Oncorhynchus mykiss) immune cells: head kidney phagocytes and peripheral blood leucocytes. Toxicology, Vol.145, No.2-3, pp. 203-215, ISSN 0300-483X.

Bols, N.C.; Brubacher, J.L.; Ganassin, R.C. \& Lee, L.E. (2001). Ecotoxicology and innate immunity in fish. Developmental \& Comparative Immunology, Vol.25, No.8-9, pp. 853873, ISSN 0145-305X.

Boshra, H.; Li, J. \& Sunyer, J.O. (2006). Recent advances on the complement system of teleost fish. Fish \& Shellfish Immunology, Vol.20, No.2, pp. 239-262, ISSN 1050-4648.

Bradbury, S.P. \& Coats, J.R. (1989). Toxicological and toxicodynamics of pyrethroid insecticide in fish. Environmental Toxicology and Chemistry, Vol.8, pp. 373-386, ISSN $1552-8618$.

Bravo, C.F.; Curtis, L.R.; Myers, M.S.; Meador, J.P.; Johnson, L.L.; Buzitis, J.; Collier, T.K.; Morrow, J.D.; Laetz, C.A.; Loge, F.J. \& Arkoosh, M.R. (2011). Biomarker responses and disease susceptibility in juvenile rainbow trout Oncorhynchus mykiss fed a high molecular weight PAH mixture. Environmental Toxicology \& Chemistry, Vol.30, No.3, pp. 704-714, ISSN 1552-8618.

Cammarata, M.; Benenati, G.; Odom, E.W.; Salerno, G.; Vizzini, A.; Vasta, G.R. \& Parrinello, N. (2007). Isolation and characterization of a fish F-type lectin from gilt head bream 
(Sparus aurata) serum. Biochimica et Biophysica Acta, Vol.1770, No. 1, pp. 150-155, ISSN 0005-2728.

Carlson, E.A.; Li, Y. \& Zelikoff, J.T. (2002). Exposure of Japanese medaka (Oryzias latipes) to benzo[a]pyrene suppresses immune function and host resistance against bacterial challenge. Aquatic Toxicology, Vol.56, No. 4, pp. 289-301, ISSN 0166-445X.

Carlson, E.A.; Li, Y. \& Zelikoff, J.T. (2004). Benzo[a]pyrene-induced immunotoxicity in Japanese medaka (Oryzias latipes): relationship between lymphoid CYP1A activity and humoral immune suppression. Toxicology and Applied Pharmacology, Vol.201, No.1, pp. 40-52, ISSN 0041-008X.

Chen, X.; Yao, G. \& Hou, Y. (2005). Pentachlorophenol reduces B lymphocyte function through proinflammatory cytokines in Carassius auratus. Food and Chemical Toxicology, Vol.43, No.2, pp. 239-245, ISSN 0278-6915.

Cleland, G.B. \& Sonstegard, R.A. (1987). Natural killer cell activity in rainbow trout (Salmo gairdneri): effect of dietary exposure to aroclor 1254 and/or mirex. Canadian Journal of Fisheries and Aquatic Sciences, Vol.44, No.3, pp. 636-638, ISSN 0706-652X.

Connon, R.E.; Geist, J.; Pfeiff, J.; Loguinov, A.V.; D'Abronzo, L.S.; Wintz, H.; Vulpe, C.D. \& Werner, I. (2009). Linking mechanistic and behavioral responses to sublethal esfenvalerate exposure in the endangered delta smelt; Hypomesus transpacificus (Fam. Osmeridae). BMC Genomics, Vol.10, pp. 608, ISSN 1471-2164.

Cossarini-Dunier, M. (1987). Effects of the pesticides atrazine and lindane and of manganese ions on cellular immunity of carp, Cyprinus carpio. Journal of Fish Biology, Vol.31, No.sA, pp. 67-73, ISSN 0022-1112.

Cossarini-Dunier, M. \& Hattenberger, A.M. (1988). Effect of pesticides (atrazine and lindane) on the replication of spring viremia of carp virus in vitro. Annales de Recherches Vétérinaires, Vol.19, No.3, pp. 209-211, ISSN 0003-4193.

Cossarini-Dunier, M.; Monod, G.; Demael, A. \& Lepot, D. (1987). Effect of gammahexachlorocyclohexane (lindane) on carp (Cyprinus carpio). I. Effect of chronic intoxication on humoral immunity in relation to tissue pollutant levels. Ecotoxicology and Environmental Safety, Vol.13, No.3, pp. 339-345, ISSN 0147-6513.

Cossarini-Dunier, M.; Demael, A. \& Siwicki, A.K. (1990). In vivo effect of the organophosphorus insecticide trichlorphon on the immune response of carp (Cyprinus carpio). I. Effect of contamination on antibody production in relation to residue level in organs. Ecotoxicology and Environmental Safety, Vol.19, No.1, pp. 9398, ISSN 0147-6513.

Costa, P.M.; Caeiro, S.; Diniz, M.S.; Lobo, J.; Martins, M.; Ferreira, A.M.; Caetano, M.; Vale, C.; DelValls, T,A. \& Costa, M.H. (2009). Biochemical endpoints on juvenile Solea senegalensis exposed to estuarine sediments: the effect of contaminant mixtures on metallothionein and CYP1A induction. Ecotoxicology, Vol.18, No.8, pp. 988-1000, ISSN 0147-6513.

Cuesta, A.; Esteban, M.A. \& Meseguer, J. (1999). Natural cytotoxic activity of gilthead seabream (Sparus aurata L.) leucocytes. Assessment by flow cytometry and microscopy. Veterinary Immunology and Immunopathology, Vol.71, No. 3-4, pp. 161171, ISSN 0165-2427.

Cuesta, A.; Meseguer, J. \& Esteban, M.A. (2008a). The antimicrobial peptide hepcidin exerts an important role in the innate immunity against bacteria in the bony fish gilthead seabream. Molecular Immunology, Vol.45, No.8, pp. 2333-2342, ISSN 1672-7681. 
Cuesta, A.; Meseguer, J. \& Esteban, M.A. (2008b). Effects of the organochlorines p,p'-DDE and lindane on gilthead seabream leucocyte immune parameters and gene expression. Fish \& Shellfish Immunology, Vol.25, No.5, pp. 682-688, ISSN 1050-4648.

Datta, S.; Ghosh, D.; Saha, D.R.; Bhattacharaya, S. \& Mazumder, S. (2009). Chronic exposure to low concentration of arsenic is immunotoxic to fish: role of head kidney macrophages as biomarkers of arsenic toxicity to Clarias batrachus. Aquatic Toxicology, Vol.92, No.2, pp. 86-94, ISSN 0166-445X.

Dautremepuits, C.; Betoulle, S.; Paris-Palacios, S. \& Vernet, G. (2004a). Immunology-related perturbations induced by copper and chitosan in carp (Cyprinus carpio L.). Archives of Environmental and Contamination Toxicology, Vol.47, No.3, pp. 370-378, ISSN 00904341.

Dautremepuits, C.; Betoulle, S.; Paris-Palacios, S. \& Vernet, G. (2004b). Humoral immune factors modulated by copper and chitosan in healthy or parasitised carp (Cyprinus carpio L.) by Ptychobothrium sp. (Cestoda). Aquatic Toxicology, Vol.68, No.4, pp. 325338, ISSN 0166-445X.

Davila, D.R.; Davis, D.A.P., Campbell, K.; Cambier, J.C.; Zigmond, L.A. \& Burchiel, S.W. (1995). Role of alterations in Ca2+-associated signaling pathways in the immunotoxicity of polycyclic aromatic hydrocarbons. Journal of Toxicology and Environmental Health Part A: Current Issues, Vol.45, No. 2, pp. 101-126, ISSN 10872620.

Duchiron, C.; Betoulle, S.; Reynaud, S. \& Deschaux, P. (2002a). Lindane increases macrophage-activating factor production and intracellular calcium in rainbow trout (Oncorhynchus mykiss) leukocytes. Ecotoxicology and Environmental Safety, Vol.53, No.3, pp. 388-396, ISSN 0147-6513.

Duchiron, C.; Reynaud, S. \& Deschaux, P. (2002b). Lindane-induced macrophage activating factor (MAF) production by peripheral blood leukocytes (PBLs) of rainbow trout (Oncorhynchus mykiss): involvement of intracellular cAMP mobilization. Aquatic Toxicology, Vol.56, No.2, pp. 81-91, ISSN 0166-445X.

Duffy, J.E. \& Zelikoff, J.T. (2006). The relationship between noncoplanar PCB-induced immunotoxicity and hepatic CYP1A induction in a fish model. Journal of Immunotoxicology, Vol.3, No.1, pp. 39-47, ISSN 1547-691X.

Duffy, J.E.; Carlson, E.; Li, Y.; Prophete, C. \& Zelikoff, J.T. (2002). Impact of polychlorinated biphenyls (PCBs) on the immune function of fish: age as a variable in determining adverse outcome. Marine Environmental Research, Vol.54, No.3-5, pp. 559-563, ISSN 0141-1136.

Duffy, J.E.; Carlson, E.A.; Li, Y.; Prophete, C. \& Zelikofft, J.T. (2003). Age-related differences in the sensitivity of the fish immune response to a coplanar PCB. Ecotoxicology, Vol.12, No.1-4, pp. 251-259, ISSN 0147-6513.

Dunier, M. \& Siwicki, A.K. (1994). Effects of lindane exposure on rainbow trout (Oncorhynchus mykiss) immunity. I. Effect of lindane on antibody-secreting cells (ASC) measured by ELISPOT assay. Ecotoxicology and Environmental Safety, Vol.27, No.1, pp. 1-6, ISSN 0147-6513.

Dunier, M.; Siwicki, A.K. \& Demaël, A. (1991). Effects of organophosphorus insecticides: effects of trichlorfon and dichlorvos on the immune response of carp (Cyprinus carpio). III. In vitro effects on lymphocyte proliferation and phagocytosis and in vivo 
effects on humoral response. Ecotoxicology and Environmental Safety, Vol.22, No.1, pp. 79-87, ISSN 0147-6513.

Dunier, M.; Siwicki, A.K.; Scholtens, J.; Dal Molin, S.; Vergnet, C. \& Studnicka, M. (1994). Effects of lindane exposure on rainbow trout (Oncorhynchus mykiss) immunity. III. Effect on nonspecific immunity and B lymphocyte functions. Ecotoxicology and Environmental Safety, Vol.27, No.3, pp. 324-334, ISSN 0147-6513.

Dunier, M.; Vergnet, C.; Siwicki, A.K. \& Verlhac, V. (1995). Effect of lindane exposure on rainbow trout (Oncorhynchus mykiss) immunity. IV. Prevention of nonspecific and specific immunosuppression by dietary vitamin $C$ (ascorbate-2-polyphosphate). Ecotoxicology and Environmental Safety, Vol.30, No.3, pp. 259-268, ISSN 0147-6513.

Dutta, H.M.; Qadri, N.; Ojha, J.; Singh, N.K.; Adhikari, S.; Datta Munshi, J.S. \& Roy, P.K. (1997). Effect of diazinon on macrophages of bluegill sunfish, Lepomis macrochirus: a cytochemical evaluation. Bulletin of Environmental Contamination and Toxicology, Vol58, No.1, pp. 135-141, ISSN 0007-4861.

Eder, K.J.; Clifford, M.A.; Hedrick, R.P.; Köhler, H.R. \& Werner, I. (2008). Expression of immune-regulatory genes in juvenile Chinook salmon following exposure to pesticides and infectious hematopoietic necrosis virus (IHNV). Fish $\mathcal{E}$ Shellfish Immunology, Vol.25, No.5, pp. 508-516, ISSN 1050-4648.

Eder, K.J.; Leutenegger, C.M.; Köhler, H.R. \& Werner, I. (2009). Effects of neurotoxic insecticides on heat-shock proteins and cytokine transcription in Chinook salmon (Oncorhynchus tshawytscha). Ecotoxicology and Environmental Safety, Vol.72, No.1, pp. 182-190, ISSN 0147-6513.

Ekman, E.; Akerman, G.; Balk, L. \& Norrgren, L. (2004). Impact of PCB on resistance to Flavobacterium psychrophilum after experimental infection of rainbow trout Oncorhynchus mykiss eggs by nanoinjection. Diseases of Aquatic Organisms, Vol.60, No.1, pp. 31-39, ISSN 0177-5103.

el-Gendy, K.S.; Aly, N.M. \& el-Sebae, A.H. (1998). Effects of edifenphos and glyphosate on the immune response and protein biosynthesis of bolti fish (Tilapia nilotica). Journal of Environmental Science and Health Part B: Pesticides, Food Contaminants, and Agricultural Wastes, Vol.33, No.2, pp. 135-149, ISSN 1093-4529.

Evans, D.L.; Graves, S.S.; Cobb, D. \& Dawe, D.L. (1984). Nonspecific cytotoxic cells in fish (Ictalurus punctatus). II. Parameters or target cell lysis and specificity. Developmental $\mathcal{E}$ Comparative Immunology, Vol.8, No.2, pp. 303-312, ISSN 0145-305X.

Faisal, M.; Weeks, B.A.; Vogelbein, W.K. \& Huggett, R.J. (1991a). Evidence of aberration of the natural cytotoxic cell activity in Fundulus heteroclitus (Pisces: Cyprinodontidae) from Elizabeth River, Virginia. Veterinary Immunology Immunopathology, Vol.29, No.3-4, pp. 339-351, ISSN 0165-2427.

Faisal, M.; Marzouk, M.S.; Smith, C.L. \& Huggett, R.J. (1991b). Mitogen induced proliferative responses of lymphocytes from spot (Leiostomus xanthurus) exposed to polycyclic aromatic hydrocarbon contaminated environments. Immunopharmacology and Immunotoxicology, Vol.13, No.3, pp. 311-327, ISSN 0892-3973.

Fatima, M.; Mandiki, S.N.; Douxfils, J.; Silvestre, F.; Coppe, P. \& Kestemont, P. (2007). Combined effects of herbicides on biomarkers reflecting immune-endocrine interactions in goldfish. Immune and antioxidant effects. Aquatic Toxicology, Vol.81, No.2, pp. 59-67, ISSN 0166-445X. 
Fletcher, T.C. (1986). Modulation of nonspecific host defenses in fish. Veterinary Immunology and Immunopathology, Vol.12, No.1-4, pp. 59-67, ISSN 0165-2427.

Frederick, L.A.; Van Veld, P.A. \& Rice, C.D. (2007). Bioindicators of immune function in creosote-adapted estuarine killifish, Fundulus heteroclitus. Journal of Toxicology and Environmental Health Part A: Current Issues, Vol.70, No.17, pp. 1433-1442, ISSN 10872620.

Galloway, T. \& Handy, R. (2003). Immunotoxicity of organophosphorous pesticides. Ecotoxicology, Vol.12, No.1-4, pp. 345-363, ISSN 0147-6513.

Gatta, P.P.; Thompson, K.D.; Smullen, R.; Piva, A.; Test, S. \& Adams, A. (2001). Dietary organic chromium supplementation and its effect on the immune response of rainbow trout (Oncorhynchus mykiss). Fish \& Shellfish Immunology, Vol.11, No.5, pp. 371-382, ISSN 1050-4648.

Gey van Pittius, M.; Van Vuren, J.H. \& Du Preez, H.H. (1992). Effects of chromium during $\mathrm{pH}$ change on blood coagulation in Tilapia sparrmanii (Cichlidae). Comparative Biochemistry and Physiology Part C: Toxicology \& Pharmacology, Vol.101, No.2, pp. 371-374, ISSN 1532-0456.

Ghanmi, Z.; Rouabhia, M.; Othmane, O. \& Deschaux, P.A. (1989). Effects of metal ions on cyprinid fish immune response: in vitro effects of $\mathrm{Zn}^{2+}$ and $\mathrm{Mn}^{2+}$ on the mitogenic response of carp pronephros lymphocytes. Ecotoxicology and Environmental Safety, Vol.17, No.2, pp. 183-189, ISSN 0147-6513.

Ghanmi, Z.; Rouabhia, M.; Alifuddin, M.; Troutaud, D. \& Deschaux, P. (1990). Modulatory effect of metal ions on the immune response of fish: in vivo and in vitro influence of $\mathrm{MnCl}_{2}$ on $\mathrm{NK}$ activity of carp pronephros cells. Ecotoxicology and Environmental Safety, Vol.20, No.3, pp. 241-245, ISSN 0147-6513.

Ghosh, S. \& Bhaattacharya, S. (1992). Elevation of C-reactive protein in serum of Chana punctatus as an indicator of water pollution. Indian Journal of Experimental Biology, Vol.30, No.8, pp. 736-737, ISSN 0019-5189.

Ghosh, D.; Datta, S.; Bhattacharya, S. \& Mazumder, S. (2007). Long-term exposure to arsenic affects head kidney and impairs humoral immune responses of Clarias batrachus. Aquatic Toxicology, Vol.81, No. 1, pp. 79-89, ISSN 0166-445X.

Girón-Pérez, M.I.; Barcelós-García, R.; Vidal-Chavez, Z.G.; Romero-Bañuelos, C.A. \& Robledo-Marenco, M.L. (2006). Effect of chlorpyrifos on the hematology and phagocytic activity of Nile tilapia cells (Oreochromis niloticus). Toxicology Mechanisms and Methods, Vol.16, No.9, pp. 495-499, ISSN 1537-6516.

Girón-Pérez, M.I.; Santerre, A.; Gonzalez-Jaime, F.; Casas-Solis, J.; Hernández-Coronado, M.; Peregrina-Sandoval, J.; Takemura, A. \& Zaitseva, G. (2007). Immunotoxicity and hepatic function evaluation in Nile tilapia (Oreochromis niloticus) exposed to diazinon. Fish \& Shellfish Immunology, Vol.23, No.4, pp. 760-769, ISSN 1050-4648.

Girón-Pérez, M.I.; Zaitseva, G.; Casas-Solis, J. \& Santerre, A. (2008). Effects of diazinon and diazoxon on the lymphoproliferation rate of splenocytes from Nile tilapia (Oreochromis niloticus): the immunosuppresive effect could involve an increase in acetylcholine levels. Fish \& Shellfish Immunology, Vol.25, No.5, pp. 517-521, ISSN 1050-4648.

Girón-Pérez, M.I.; Velázquez-Fernández, J.; Díaz-Resendiz, K.; Díaz-Salas, F.; CantoMontero, C.; Medina-Díaz, I.; Robledo-Marenco, M.; Rojas-García, A. \& Zaitseva, G. (2009). Immunologic parameters evaluations in Nile tilapia (Oreochromis niloticus) 
exposed to sublethal concentrations of diazinon. Fish $\mathcal{E}$ Shellfish Immunology, Vol.27, No.2, pp. 383-385, ISSN 1050-4648.

Gómara, B.; Bordajandi, L.R.; Fernández, M.A.; Herrero, L.; Abad, E.; Abalos, M.; Rivera, J. \&, González, M.J. (2005). Levels and trends of polychlorinated dibenzo-pdioxins/furans (PCDD/Fs) and dioxin-like polychlorinated biphenyls (PCBs) in Spanish commercial fish and shellfish products, 1995-2003. Journal of Agricultural and Food Chemistry, Vol.53, No.21, pp. 8406-8413, ISSN 0021-8561.

Grinwis, G.C.; Vethaak, A.D.; Wester, P.W. \& Vos, J.G. (2000). Toxicology of environmental chemicals in the flounder (Platichthys flesus) with emphasis on the immune system: field, semi-field (mesocosm) and laboratory studies. Toxicology Letters, Vol.15, No.112-113, pp. 289-301, ISSN 0378-4274.

Hansen, B.H.; Garmo, O.A.; Olsvik, P.A. \& Andersen, R.A. (2007). Gill metal binding and stress gene transcription in brown trout (Salmo trutta) exposed to metal environments: the effect of pre-exposure in natural populations. Environmental Toxicology \& Chemistry, Vol.26, No,5, pp. 944-953, ISSN 1552-8618.

Harford, A.J.; O'Halloran, K. \& Wright, P.F.A. (2005). The effects of in vitro pesticide exposures on the phagocytic function of four native Australian freshwater fish. Aquatic Toxicology, Vol.75, No.4, pp. 330-342, ISSN 0166-445X.

Hart, L.J.; Smith, S.A.; Smith, B.J.; Roberston, J.; Besteman, E.G. \& Holladay, S.D. (1998). Subacute immunotoxic effects of the polycyclic aromatic hydrocarbon 7,12dimethylbenzanthracene (DMBA) on spleen and pronephros leukocytic cell counts and phagocytic cell activity in tilapia (Oreochromis niloticus). Aquatic Toxicology, Vol.41, No.1-2, pp. 17-29, ISSN 0166-445X.

Hermann, A.C. \& Kim, C.H. (2005). Effects of arsenic on zebrafish innate immune system. Marine Biotechnology (NY), Vol.7, No.5, pp. 494-505, ISSN 0025-3162.

Hetrick, F.M.; Knittel, M.D. \& Fryer, J.L. (1979). Increased susceptibility of rainbow trout to infectious haematopoietic necrosis virus after exposure to copper. Applied and Environmental Microbiology, Vol.37, No.2, pp. 198-201, ISSN 0099-2240.

Hikima, J.I.; Jung, T.S. \& Aoki, T. (2011). Immunoglobulin genes and their transcriptional control in teleosts. Developmental $\mathcal{E}$ Comparative Immunology, doi:10.1016/j.dci.2010.10.011, ISSN 0145-305X.

Hinck, J.E.; Blazer, V.S.; Denslow, N.D.; Myers, M.S.; Gross, T.S. \& Tillitt, D.E. (2007). Biomarkers of contaminant exposure in Northern Pike (Esox lucius) from the Yukon River Basin, Alaska. Archives of Environmental Contamination and Toxicology, Vol.52, No.4, pp. 549-562, ISSN 0090-4341.

Hoeger, B.; van den Heuvel, M.R.; Hitzfeld, B.C. \& Dietrich, D.R. (2004). Effects of treated sewage effluent on immune function in rainbow trout (Oncorhynchus mykiss). Aquatic Toxicology, Vol.70, No.4, pp. 345-355, ISSN 0166-445X.

Holladay, S.D.; Smith, S.A.; Besteman, E.G.; Deyab, A.S.M.I.; Gogal, R.M.; Hrubec, T.; Robertson, J.L. \& Ahmed, S.A. (1998). Benzo[a]pyrene-induced hypocellularity of the pronephros in tilapia (Oreochromis niloticus) is accompanied by alterations in stromal and parenchymal cells and by enhanced immune cell apoptosis. Veterinary Immunology and Immunopathology, Vol.64, No.1, pp. 69-82, ISSN 0165-2427.

Holland, M.C.H. \& Lambris, J.D. (2002). The complement system in teleosts. Fish $\mathcal{E}$ Shellfish Immunology, Vol.12, No.5, pp. 399-420, ISSN 1050-4648. 
Hsu, E.; Pulham. N.; Rumfelt, L.L. \& Flajnik, M.F. (2006). The plasticity of immunoglobulin gene systems in evolution. Immunologycal Reviews, Vol.210, No.1, pp. 8-26, ISSN 1474-1733.

Hutchinson, T.H.; Field, M.D. \& Manning, M.J. (2003). Evaluation of non-specific immune functions in dab, Limanda limanda L., following short-term exposure to sediments contaminated with polyaromatic hydrocarbons and/or polychlorinated biphenyls. Marine Environmental Research, Vol.55, No.3, pp. 193-202, ISSN 0141-1136.

Iwanowicz, L.R.; Lerner, D.T.; Blazer, V.S. \& McCormick, S.D. (2005). Aqueous exposure to Aroclor 1254 modulates the mitogenic response of Atlantic salmon anterior kidney T-cells: indications of short- and long-term immunomodulation. Aquatic Toxicology, Vol.72, No.4, pp. 305-314, ISSN 0166-445X.

Iwanowicz, L.R.; Blazer, V.S.; McCormick, S.D.; Vanveld, P.A. \& Ottinger, C.A. (2009). Aroclor 1248 exposure leads to immunomodulation, decreased disease resistance and endocrine disruption in the brown bullhead, Ameiurus nebulosus. Aquatic Toxicology, Vol.93, No.1, pp. 70-82, ISSN 0166-445X.

Jin, Y.; Chen, R.; Liu, W. \& Fu, Z. (2010). Effect of endocrine disrupting chemicals on the transcription of genes related to the innate immune system in the early developmental stage of zebrafish (Danio rerio). Fish \& Shellfish Immunology, Vol.28, No.5-6, pp. 854-861, ISSN 1050-4648.

Kaattari, S.L. \& Piganelli, J.D. (1997). Immunization with bacterial antigens: bacterial kidney disease. Developments in Biological Standardization, Vol.90, pp. 145-152, ISSN 03015149 .

Karrow, N.A.; Bols, N.C.; Whyte, J.J.; Solomon, K.R.; Dixon, D.G. \& Boermans, H.J. (2001). Effects of creosote exposure on rainbow trout pronephros phagocyte activity and the percentage of lymphoid B cells. Journal of Toxicology and Environmental Health Part A: Current Issues, Vol.63, No.5, pp. 363-381, ISSN 1087-2620.

Khalaf-Allah, S.S. (1999). Effect of pesticide water pollution on some haematological, biochemical and immunological parameters in Tilapia nilotica fish. Deutsche Tierarztliche Wochenschrift, Vol.106, No.2, pp. 67-71, ISSN 0341-6593.

Khan, R.A. (2003). Health of flatfish from localities in Placentia Bay, Newfoundland, contaminated with petroleum and PCBs. Archives of Environmental Contamination and Toxicology, Vol.4, No.4, pp. 485-492, ISSN 0090-4341.

Khangarot, B.S. \& Tripathi, D.M. (1991). Changes in humoral and cell-mediated immune responses and in skin and respiratory surfaces of catfish, Saccobranchus fossilis following copper exposure. Ecotoxicology and Environmental Safety, Vol.22, No.3, pp. 291-308, ISSN 0147-6513.

Khangarot, B.S. \& Rathore, R.S. (1999). Copper exposure reduced the resistance of the catfish Saccobranchus fossilis to Aeromonas hydrophila infection. Bulletin of Environmental Contamination $\mathcal{E}$ Toxicology, Vol.62, No.4, pp. 490-495, ISSN 0007-4861.

Khangarot, B.S.; Ray, P.K. \& Singh, K.P. (1988). Influence of copper treatment on the immune response in an air breathing teleost, Saccobranchus fossillis. Bulletin of Environmental Contamination \& Toxicology, Vol.41, pp. 222-226, ISSN 0007-4861.

Khangarot, B.S.; Rathore, R.S. \& Tripathi, D.M. (1999). Effects of chromium on humoral and cell-mediated immune responses and host resistance to disease in a Freshwater catfish, Saccobranchus fossilis (Bloch). Ecotoxicology and Environmental Safety, Vol.43, No.1, pp. 11-20, ISSN 0147-6513. 
Knittel, M.D. (1981). Susceptibility of steelhead trout Salmo gairdneri Richardson to redmouth infection Yersinia ruckeri following exposure to copper. Journal of Fish Diseases, Vol.4, No.1, pp. 33-40, ISSN 0140-7775.

Kranz, H. \& Gercken, J. (1987). Effects of sublethal concentrations of potassium dichromate on the occurrence of splenic melano-macrophage centres in juvenile plaice, Pleuronectes platessa, L. Journal of Fish Biology, Vol.31, No.sA, pp. 75-80, ISSN 00221112.

Kreutz, L.C.; Barcellos, L.J.; Marteninghe, A.; Dos Santos, E.D. \& Zanatta, R. (2010). Exposure to sublethal concentration of glyphosate or atrazine-based herbicides alters the phagocytic function and increases the susceptibility of silver catfish fingerlings (Rhamdia quelen) to Aeromonas hydrophila challenge. Fish $\mathcal{E}$ Shellfish Immunology, Vol.29, No.4, pp. 694-697, ISSN 1050-4648.

Lee, R.F. \& Anderson, J.W. (2005). Significance of cytochrome P450 system responses and levels of bile fluorescent aromatic compounds in marine wildlife following oil spills. Marine Pollution Bulletin, Vol.50, No.7, pp. 705-723, ISSN 0025-326X.

Lemaire-Gony, S.; Lemaire, P. \& Pulsford, A.L. (1995). Effects of cadmium and benzo[a]pyrene on the immune system, gill ATPase and EROD activity of European sea bass Dicentrarchus labrax. Aquatic Toxicology, Vol.31, No.4, pp. 297313, ISSN 0166-445X.

Lock, R.A. \& van Overbeeke, A.P. (1981). Effects of mercuric chloride and methylmercuric chloride on mucus secretion in rainbow trout, Salmo gairdneri Richardson. Comparative Biochemistry and Physiology Part C: Toxicology \& Pharmacology, Vol.69C, No.1, pp. 67-73, ISSN 1532-0456.

Low, K.W. \& Sin, Y.M. (1998). Effects of mercuric chloride and sodium selenite on some immune responses of blue gourami, Trichogaster trichopterus (Pallus). Science of the Total Environment, Vol.214, No.1-3, pp. 153-164, ISSN 0048-9697.

Luebke, R.W.; Hodson, P.V.; Faisal, M.; Ross, P.S.; Grasman, K.A. \& Zelikoff, J. (1997). Aquatic pollution-induced immunotoxicity in wildlife species. Fundamental and Applied Toxicology, Vol.37, No.1, pp. 1-15, ISSN 0272-0590.

Lugo, R.S.; Nathalí, G.; Villalobos, L.B. \& Mairin, L. (2006). Immunological response of the freshwater fish Colossoma macropomum as a biomarker of copper exposure. Bulletin of Environmental Contamination $\mathcal{E}$ Toxicology, Vol.77, No. 6, pp. 925-930, ISSN 00074861.

MacDougal, K.C.; Johnson, M.D. \& Burnett, K.G. (1996). Exposure to mercury alters early activation events in fish leukocytes. Environmental Health Perspectives, Vol.104, No.10, pp. 1102-1106, ISSN: 0091-6765.

Magnadottir, B. (2006). Innate immunity of fish (overview). Fish $\mathcal{E}$ Shellfish Immunology, Vol.20, No.2, pp. 137-151, ISSN 1050-4648.

Manning, M.J. (1998). Immune defence systems, In: Biology of farmed fish, K.D. Black \& A.D. Pickering, (Eds.), 180-221, Sheffield Academic Press, ISBN 1-85075-877-8, Sheffield, UK.

Maule, A.G.; Jørgensen, E.H.; Vijayan, M.M. \& Killie, J.E. (2005). Aroclor 1254 exposure reduces disease resistance and innate immune responses in fasted Arctic charr. Environmental Toxicology \& Chemistry, Vol.24, No.1, pp. 117-124, ISSN 1552-8618. 
Meseguer, J.; López-Ruíz, A. \& Esteban, M.A. (1994). Cytochemical characterization of leucocytes from the seawater teleost, gilthead seabream (Sparus aurata L.). Histochemistry, Vol.102, No.1, pp. 37-44, ISSN 0022-1554.

Miller, N.; Wilson, M.; Bengten, E.; Stuge, T.; Warr, G. \& Clem, W. (1998). Functional and molecular characterization of teleost leukocytes. Immunological Reviews, Vol.166, pp. 187-197, ISSN 1600-065X.

Milston, R.H.; Fitzpatrick, M.S.; Vella, A.T.; Clements, S.; Gundersen, D.; Feist, G.; Crippen, T.L.; Leong, J. \& Schreck, C.B. (2003). Short-term exposure of Chinook salmon (Oncoryhnchus tshawytscha) to o,p-DDE or DMSO during early life-history stages causes long-term humoral immunosuppression. Environmental Health Perspectives, Vol.111, No.13, pp. 1601-1607, ISSN 0091-6765.

Misra, S.; Zafarullah, M.; Price-Haughey, J. \& Gedamu, L. (1989). Analysis of stress-induced gene expression in fish cell lines exposed to heavy meals and heat shock. Biochimica et Biophysica Acta, Vol.1007, No.3, pp. 325-333, ISSN 0005-2728.

Misumi, I.; Vella, A.T.; Leong, J.A.; Nakanishi, T. \& Schreck, C.B. (2005). p,p'-DDE depresses the immune competence of Chinook salmon (Oncorhynchus tshawytscha) leukocytes. Fish \& Shellfish Immunology, Vol.19, No.2, pp. 97-114, ISSN 1050-4648.

Muhvich, A.G.; Jones, R.T.; Kane, A.S.; Anderson, R.S. \& Reimscheussel, R. (1995). Effects of chronic copper exposure on the macrophage chemiluminescent response and gill histology in goldfish (Carassius auratus L.). Fish \& Shellfish Immunology, Vol.5, No.4, pp. 251-264, ISSN 1050-4648.

Nakayama, K.; Kitamura, S.; Murakami, Y.; Song, J.Y.; Jung, S.J.; Oh, M.J.; Iwata, H. \& Tanabe, S. (2008). Toxicogenomic analysis of immune system-related genes in Japanese flounder (Paralichthys olivaceus) exposed to heavy oil. Marine Pollution Bulletin, Vol.57, No.6-12, pp. 445-452, ISSN 0025-326X.

Nayak, A.K.; Das, B.K.; Kohli, M.P. \& Mukherjee, S.C. (2004). The immunosuppressive effect of alpha-permethrin on Indian major carp, rohu (Labeo rohita Ham.). Fish \& Shellfish Immunology, Vol.16, No.1, pp. 41-50, ISSN 1050-4648.

Nayak, A.S.; Lage, C.R. \& Kim, C.H. (2007). Effects of low concentrations of arsenic on the innate immune system of the zebrafish (Danio rerio). Toxicological Sciences, Vol.98, No.1, pp. 118-124, ISSN 1096-6080.

O'Halloran, A.J.; Ahokas, J.T. \& Wright, P.F.A. (1996). In vitro responses of fish immune cells to three classes of pesticides. In: Modulators of Immune Responses: The Evolutionary Trail, J.S. Stolen, T.C. Fletcher, C.J. Bayne, C.J. Secombes, J.T. Zelikoff, L.E. Twerdok \& D.P. Anderson (Eds.), 531-534, SOS Publications, ISBN 978-188705-200-9, Fair Haven, NJ, USA.

O'Halloran, K.; Ahokas, J.T. \& Wright, P.F.A. (1998). Response of fish immune cells to in vitro organotin exposures. Aquatic Toxicology, Vol.40, No.2-3, pp. 141-156, ISSN 0166-445X.

O'Neill, G. (1981). The humoral response of Salmo trutta L. and Cyprinus carpio L. exposed to heavy metals. Journal of Fish Biology, Vol.19, No.3, pp. 297-306, ISSN 0022-1112.

Ortiz-Delgado, J.B, \& Sarasquete, C. (2004). Toxicity, histopathological alterations and immunohistochemical CYP1A induction in the early life stages of the seabream, Sparus aurata, following waterborne exposure to $\mathrm{B}(\mathrm{a}) \mathrm{P}$ and TCDD. Journal of Molecular Histology, Vol.35, No.1, pp. 29-45, ISSN 1567-2379. 
Paul, I.; Mandal, C. \& Mandal, C. (1998). Effect of environmental pollutants on the Creactive protein of a freshwater major carp, Catla catla. Developmental $\mathcal{E}$ Comparative Immunology, Vol.22, No.5-6, pp. 519-532, ISSN 0145-305X.

Payne, J.F. \& Fancey, L.F. (1989). Effect of polycyclic aromatic hydrocarbons on immune responses in fish: Changes in melano-macrophage centers in flounder (Pseudopleuronectes americanus) exposed to hydrocarbon-contaminated sediments. Marine Environmental Research, Vol.28, No.1-4, pp. 431-435, ISSN 0141-1136.

Pimpão, C.T.; Zampronio, A.R.; Silva de Assis, H.C. (2008). Exposure of Ancistrus multispinis (Regan, 1912, Pisces, Teleostei) to deltamethrin: effects on cellular immunity. Fish $\mathcal{E}$ Shellfish Immunology, Vol.25No.5, pp. 528-532, ISSN 1050-4648.

Powell, D.B.; Palm, R.C.Jr; Skillman, A. \& Godtfredsen, K. (2003). Immunocompetence of juvenile Chinook salmon against Listonella anguillarum following dietary exposure to Aroclor 1254. Environmental Toxicology \& Chemistry, Vol.22, No.2, pp. 285-295, ISSN 1552-8618.

Prabakaran, M.; Binuramesh, C.; Steinhagen, D. \& Michael, R.D. (2006). Immune response and disease resistance of Oreochromis mossambicus to Aeromonas hydrophila after exposure to hexavalent chromium. Diseases of Aquatic Organisms, Vol.68, No.3, pp. 189-196, ISSN 0177-5103.

Prabakaran, M., Binuramesh, C., Steinhagen, D. \& Dinakaran, M.R. (2007). Immune response in the tilapia, Oreochromis mossambicus on exposure to tannery effluent. Ecotoxicology and Environmental Safety, Vol.68, No.3, pp. 372-378, ISSN 0147-6513.

Quabius, E.S.; Krupp, G. \& Secombes, C.J. (2005). Polychlorinated biphenyl 126 affects expression of genes involved in stress-immune interaction in primary cultures of rainbow trout anterior kidney cells. Environmental Toxicology \& Chemistry, Vol.24, no.12, pp. 3053-3060, ISSN 1552-8618.

Reynaud, S. \& Deschaux, P. (2005). The effects of 3-methylcholanthrene on lymphocyte proliferation in the common carp (Cyprinus carpio L.). Toxicology, Vol.211, No.1-2, pp. 156-164, ISSN 0300-483X.

Reynaud, S. \& Deschaux, P. (2006). The effects of polycyclic aromatic hydrocarbons on the immune system of fish: a review. Aquatic Toxicology, Vol.77, No.2, pp. 229-238, ISSN 0166-445X.

Reynaud, S.; Marionnet, D.; Taysse, L., Duchiron, C. \& Deschaux, P. (2002). The effects of 3methylcholanthrene on macrophage respiratory burst and biotransformation activities in the common carp (Cyprinus carpio L). Fish $\mathcal{E}$ Shellfish Immunology, Vol.12, No.1, pp. 17-34, ISSN 1050-4648.

Reynaud, S.; Duchiron, C. \& Deschaux, P. (2003). 3-Methylcholanthrene inhibits lymphocyte proliferation and increases intracellular calcium levels in common carp (Cyprinus carpio L). Aquatic Toxicology, Vol.63, No.3, pp. 319-331, ISSN 0166-445X.

Rice, C.D. \& Schlenk, D. (1995). Immune function and cytochrome P450 1A activity after acute exposure to 3,3',4,4',5-pentachlorobiphenyl (PCB 126) in channel catfish. Journal of Aquatic Animal Health, Vol.7, No.3, pp. 195-204, ISSN 0899-7659.

Rice, C.D.; Banes, M.M. \& Ardelt, T.C. (1995). Immunotoxicity in channel catfish, Ictalurus punctatus, following acute exposure to tributyltin. Archives of Environmental Contamination and Toxicology, Vol.28, No.4, pp. 464-470, ISSN 0090-4341.

Robertsen, B. (2006). The interferon system of teleost fish. Fish $\mathcal{E}$ Shellfish Immunology, Vol.20, No.2, pp. 172-191, ISSN 1050-4648. 
Robohm, R.A. (1986). Paradoxical effects of cadmium exposure on antibacterial antibody responses in two fish species: inhibition in cunners (Tautogolabrus adspersus) and enhancement in striped bass (Morone saxatilis). Veterinary Immunology and Immunopathology, Vol.12, No.1-4, pp. 251-262, ISSN 0165-2427.

Rombout, J.H. \& Huttenhuis, H.B.; Picchietti, S. \& Scapigliati, G. (2005). Phylogeny and ontogeny of fish leucocytes. Fish E Shellfish Immunology, Vol.19, No.5, pp. 441-455, ISSN 1050-4648.

Rougier, F.; Troutaud, D.; Ndoye, A. \& Deschaux, P. (1994). Non-specific immune response of Zebrafish, Brachydanio rerio (Hamilton-Buchanan) following copper and zinc exposure. Fish $\mathcal{E}$ Shellfish Immunology, Vol.4, No.2, pp. 115-127, ISSN 1050-4648.

Sarmento, A.; Guilhermino, L. \& Afonso, A. (2004). Mercury chloride effects on the function and cellular integrity of sea bass (Dicentrarchus labrax) head kidney macrophages. Fish E Shellfish Immunology, Vol.17, No.5, pp. 489-498, ISSN 1050-4648.

Schmitt, C.J.; Hinck, J.E.; Blazer, V.S.; Denslow, N.D.; Dethloff, G.M.; Bartish, T.M.; Coyle, J.J. \& Tillitt, D.E. (2005). Environmental contaminants and biomarker responses in fish from the Rio Grande and its U.S. tributaries: spatial and temporal trends. Science of the Total Environment, Vol.350, No.1-3, pp. 161-193, ISSN 0048-9697.

Schuwerack, P.M.; Lewis, J.W. \& Hoole, D. (2003). Cadmium-induced cellular and immunological responses in Cyprinus carpio infected with the blood parasite, Sanguinicola inermis. Journal of Helminthology, Vol.77, No.4, pp. 341-350, ISSN 0022149X.

Secombes, C.J. (1996). The non-specific immune system. cellular defenses. In: The Fish Immune System, Organism, Pathogen and Environment, G. Iwama \& T. Nakanishi, (Eds.), 63-103, Academic Press, ISBN 978-0123504395, London, UK.

Secombes, C.J.; Bird, S. \& Zou, J. (2005). Adaptive immunity in teleosts: cellular immunity. Developments in Biologicals, Vol.121, pp. 25-32, ISSN 1424-6074.

Seeley, K.R. \& Weeks-Perkins, B.A. (1997). Suppression of natural cytotoxic cell and macrophage phagocytic function in oyster toadfish exposed to 7,12dimethylbenz[a]anthracene. Fish $\mathcal{E}$ Shellfish Immunology, Vol.7, No.2, pp. 115-121, ISSN 1050-4648.

Shariff, M.; Jayawardena, P.A.H.L.; Yusoff, F.M. \& Subasinghe, R. (2001). Immunological parameters of Javanese carp Puntius gonionotus (Bleeker) exposed to copper and challenged with Aeromonas hydrophila. Fish \& Shellfish Immunologyogy, Vol.11, No.4, pp. 281-291, ISSN 1050-4648.

Shelley, L.K.; Balfry, S.K.; Ross, P.S. \& Kennedy, C.J. (2009). Immunotoxicological effects of a sub-chronic exposure to selected current-use pesticides in rainbow trout (Oncorhynchus mykiss). Aquatic Toxicology, Vol.92, No.2, pp. 95-103, ISSN 0166-445X.

Shen, L.; Stuge, T.B.; Zhou, H.; Khayat, M.; Barker, K.S.; Quiniou, S.M.; Wilson, M.; Bengten, E.; Chinchar, V.G.; Clem, L.W. \& Miller, N.W. (2002). Channel catfish cytotoxic cells: a mini-review. Developmental \& Comparative Immunology, Vol.26, No.2, pp. 141149, ISSN 0145-305X.

Siwicki, A.K. \& Dunier, M. (1994). Effects of lindane exposure on rainbow trout (Oncorhynchus mykiss) immunity. II. In vitro restoration of antibody-secreting cells and lymphocyte proliferation activity by nitrogranulogen after in vivo immunosuppression due to lindane. Ecotoxicology and Environmental Safety, Vol.27, No.3, pp. 316-323, ISSN 0147-6513. 
Siwicki, A.K.; Cossarini-Dunier, M.; Studnicka, M. \& Demael, A. (1990). In vivo effect of the organophosphorus insecticide trichlorphon on immune response of carp (Cyprinus carpio). II. Effect of high doses of trichlorphon on nonspecific immune response. Ecotoxicology and Environmental Safety, Vol.19, No.1, pp. 99-105, ISSN 0147-6513.

Siwicki, A.K.; Terech-Majewska, E.; Grudniewska, J.; Malaczewska, J.; Kazun, K. \& Lepa, A. (2010). Influence of deltamethrin on nonspecific cellular and humoral defense mechanisms in rainbow trout (Oncorhynchus mykiss). Environmental Toxicology and Chemistry, Vol29, No.3, pp. 489-491, ISSN 1552-8618.

Skupinska, K.; Misiewicz, I. \& Kasprzycka-Guttman, T. (2004). Polycyclic aromatic hydrocarbons: physicochemical properties, environmental appearance and impact on living organisms. Acta Poloniae Pharmaceutica, Vol.61, No.3, pp. 233-240, ISSN 0001-6837.

Smith, D.A.; Schurig, G.G.; Smith, S.A. \& Holladay, S.D. (1999). The hemolitic plaqueforming cell assay in tilapia (Oreochromis niloticus) exposed to benzo[a]pyrene: enhanced or depressed plaque formation depends on dosing schedule. Toxicological Methods, Vol.9, No.2, pp. 57-70, ISSN 1051-7235.

Spitsbergen, J.M.; Schat, K.A.; Kleeman, J.M. \& Peterson, R.E. (1986). Interactions of 2,3,7,8tetrachlorodibenzo-p-dioxin (TCDD) with immune responses of rainbow trout. Veterinary Immunology Immunopathology, Vol.12, No.1-4, pp. 263-280, ISSN 01652427.

Steinhagen, D.; Helmus, T.; Maurer, S.; Michael, R.D.; Leibold, W.; Scharsack, J.P.; Skouras, A, \& Schuberth, H.J. (2004). Effect of hexavalent carcinogenic chromium on carp Cyprinus carpio immune cells. Diseases of Aquatic Organisms, Vol.62, No.1-2, pp. 155161, ISSN 0177-5103.

Sudhan, T. \& Michael, R.D. (1995). Modulation of humoral immune response by tannery effluent in Oreochromis mossambicus (Peters). Indian Journal of Experimental Biology, Vol.33, No.10, pp. 793-795, ISSN 0019-5189.

Suresh, N. (2009). Effect of cadmium chloride on liver, spleen and kidney melano macrophage centres in Tilapia mossambica. Journal of Environmental Biology, Vol.30, No.4, pp. 505-508, ISSN 0254-8704.

Sures, B. \& Knopf, K. (2004). Individual and combined effects of cadmium and 3,3',4,4',5pentachlorobiphenyl (PCB 126) on the humoral immune response in European eel (Anguilla anguilla) experimentally infected with larvae of Anguillicola crassus (Nematoda). Parasitology, Vol.128, No.4, pp. 445-454, ISSN 0031-1847.

Sweet, L.I. \& Zelikoff, J.T. (2001). Toxicology and immunotoxicology of mercury: a comparative review in fish and humans. Journal of Toxicology and Environmental Health Part B: Critical Reviews, Vol.4, No.2, pp. 161-205, ISSN 1093-7404.

Tahir, A. \& Secombes, C.J. (1995). The effects of diesel oil-based drilling mud extracts on immune responses of rainbow trout. Archives of Environmental Contamination and Toxicology, Vol.29, No.1, pp. 27-32, ISSN 0090-4341.

Taysse, L.; Troutaud, D.; Khan, N.A. \& Deschaux, P. (1995). Structure-activity relationship of phenolic compounds (phenol, pyrocatechol and hydroquinone) on natural lymphocytotoxicity of carp (Cyprinus carpio). Toxicology, Vol.98, No.1-3, pp. 207-214, ISSN 0300-483X.

Teles, M.; Mackenzie, S.; Boltaña, S.; Callol, A. \& Tort, L. (2011). Gene expression and TNFalpha secretion profile in rainbow trout macrophages following exposures to 
copper and bacterial lipopolysaccharide. Fish \& Shellfish Immunology, Vol.30, No.1, pp. 340-346, ISSN 1050-4648.

Tellez-Bañuelos, M.C.; Santerre, A.; Casas-Solis, J.; Bravo-Cuellar, A. \& Zaitseva, G. (2009). Oxidative stress in macrophages from spleen of Nile tilapia (Oreochromis niloticus) exposed to sublethal concentration of endosulfan. Fish $\mathcal{E}$ Shellfish Immunology, Vol.27, No.2, pp. 105-111, ISSN 1050-4648.

Tellez-Bañuelos, M.C.; Santerre, A.; Casas-Solis, J. \& Zaitseva, G. (2010). Endosulfan increases seric interleukin-2 like (IL-2L) factor and immunoglobulin $\mathrm{M}(\operatorname{IgM})$ of Nile tilapia (Oreochromis niloticus) challenged with Aeromonas hydrophila. Fish $\mathcal{E}$ Shellfish Immunology, Vol.28, No.2, pp. 401-405, ISSN 1050-4648.

van der Weiden, M.E.J.; Bleumick, R.; Seinen, W. \& van den Berg, M. (1994). Concurrence of P450 1A induction and toxic effects in the mirror carp (Cyprinus carpio), after administration of a low dose of 2,3,7,8-tetrachlorodibenzo-p-dioxin. Aquatic Toxicology, Vol.29, No.3-4, pp. 147-162, ISSN 0166-445X.

Velma, V., Vutukuru, S.S. \& Tchounwou, P.P. (2009). Ecotoxicology of Hexavalent Chromium in Freshwater Fish: A Critical Review. Reviews on Environmental Health, Vol.24, No.2, pp. 129-145, ISSN 0048-7554.

Walczak, B.Z.; Blunt, B.R. \& Hodson, P.V. (1987). Phagocytic function of monocytes and haematological changes in rainbow trout injected intraperitoneally with benzo(a)pyrene $(\mathrm{BaP})$ and benzo(a)anthracene (BaA). Journal of Fish Biology, Vol.31, No.sA, pp. 251-253, ISSN 0022-1112.

Weeks, B.A. \& Warinner, J.E. (1984). Effects of toxic chemicals on macrophage phagocytosis of two estuarine fishes. Marine Environmental Research, Vol.14, No.1-4, pp. 327-335, ISSN 0141-1136.

Weeks, B.A.; Warinner, J.E.; Mason, P.L. \& McGinnis, D.S. (1986). Influence of toxic chemicals on the chemotactic response of fish macrophages. Journal of Fish Biology, Vol.28, No.6, pp. 653-658, ISSN 0022-1112.

Wepener ,V.; Van Vuren, J.H.J. \& Du Preez, H.H. (1992). The effect of hexavalent chromium at different $\mathrm{pH}$ values on the hematology of Tilapia sparrmanii (Cichlidae). Comparative Biochemistry and Physiology Part C: Toxicology \& Pharmacology, Vol.101, no.2, pp. 375-381, ISSN 1532-0456.

Wilson, M.R.; Marcuz, A.; van Ginkel, F.; Miller, N.W.; Clem, L.W. \& Middleton, D. (1990). The immunoglobulin $M$ heavy chain constant region gene of the channel catfish, Ictalurus punctatus: an unusual mRNA splice pattern produces the membrane form of the molecule. Nucleic Acids Research, Vol.18, No.17, pp. 5227-5233, ISSN 03051048.

Winkelhake, J.L.; Vodicnik, M.J. \& Taylor, J.L. (1983). Induction in rainbow trout of an acute phase (C-reactive) protein by chemicals of environmental concern. Comparative Biochemistry and Physiology Part C: Toxicology E Pharmacology, Vol.74, No.1, pp. 5558, ISSN 1532-0456.

Wu, S.M.; Shih, M.J. \& Ho, Y.C. (2007). Toxicological stress response and cadmium distribution in hybrid tilapia (Oreochromis sp.) upon cadmium exposure. Comparative Biochemistry and Physiology Part C: Toxicology \& Pharmacology, Vol.145, No.2, pp. 218-226, ISSN 1532-0456.

Zelikoff, J.T.; Bowser, D.; Squibb, K.S. \& Frenkel, K. (1995). Immunotoxicity of low level cadmium exposure in fish: an alternative animal model for immunotoxicological 
studies. Journal of Toxicology and Environmental Health Part A: Current Issues, Vol.45, No.3, pp. 235-248, ISSN 1087-2620.

Zelikoff, J.T., Wang, W., Islam, N., Flescher, E., (1996). Assays of reactive oxygen intermediates and antioxidant enzymes in medaka (Oryzias latipes): potential biomarkers for predicting the effects of environmental pollution. In: Techniques in Aquatic Toxicology, G. K. Ostrander, (Ed.), 178-206, CRC Press, ISBN 1-56670-149-X, Boca Raton, FL, USA.

Zhou, Q.; Zhang, J.; Fu, J.; Shi, J. \& Jiang, G. (2008). Biomonitoring: An appealing tool for assessment of metal pollution in the aquatic ecosystem. Analytica Chimica Acta, Vol.606, No.2, pp. 135-150, ISSN 0003-2670. 


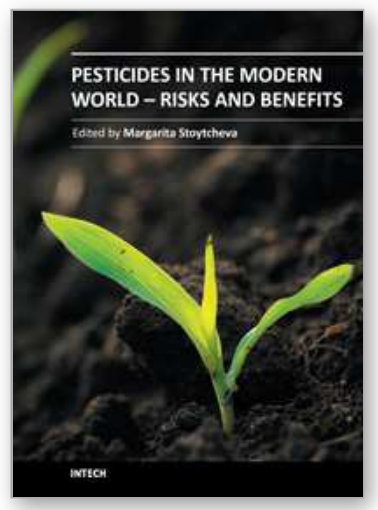

\author{
Pesticides in the Modern World - Risks and Benefits \\ Edited by Dr. Margarita Stoytcheva
}

ISBN 978-953-307-458-0

Hard cover, 560 pages

Publisher InTech

Published online 03, October, 2011

Published in print edition October, 2011

This book is a compilation of 29 chapters focused on: pesticides and food production, environmental effects of pesticides, and pesticides mobility, transport and fate. The first book section addresses the benefits of the pest control for crop protection and food supply increasing, and the associated risks of food contamination. The second book section is dedicated to the effects of pesticides on the non-target organisms and the environment such as: effects involving pollinators, effects on nutrient cycling in ecosystems, effects on soil erosion, structure and fertility, effects on water quality, and pesticides resistance development. The third book section furnishes numerous data contributing to the better understanding of the pesticides mobility, transport and fate. The addressed in this book issues should attract the public concern to support rational decisions to pesticides use.

\title{
How to reference
}

In order to correctly reference this scholarly work, feel free to copy and paste the following:

Alberto Cuesta, José Meseguer and M. Angeles Esteban (2011). Immunotoxicological Effects of Environmental Contaminants in Teleost Fish Reared for Aquaculture, Pesticides in the Modern World - Risks and Benefits, Dr. Margarita Stoytcheva (Ed.), ISBN: 978-953-307-458-0, InTech, Available from:

http://www.intechopen.com/books/pesticides-in-the-modern-world-risks-and-benefits/immunotoxicologicaleffects-of-environmental-contaminants-in-teleost-fish-reared-for-aquaculture

\section{INTECH}

open science | open minds

\author{
InTech Europe \\ University Campus STeP Ri \\ Slavka Krautzeka 83/A \\ 51000 Rijeka, Croatia \\ Phone: +385 (51) 770447 \\ Fax: +385 (51) 686166 \\ www.intechopen.com
}

\author{
InTech China \\ Unit 405, Office Block, Hotel Equatorial Shanghai \\ No.65, Yan An Road (West), Shanghai, 200040, China \\ 中国上海市延安西路65号上海国际贵都大饭店办公楼 405 单元 \\ Phone: +86-21-62489820 \\ Fax: +86-21-62489821
}


(C) 2011 The Author(s). Licensee IntechOpen. This is an open access article distributed under the terms of the Creative Commons Attribution 3.0 License, which permits unrestricted use, distribution, and reproduction in any medium, provided the original work is properly cited. 